\title{
EFFECT OF COLD FRONTS ON THE BENTHIC MACROFAUNA OF EXPOSED SANDY BEACHES WITH CONTRASTING MORPHODYNAMICS
}

\author{
Eliana dos Santos Alves ${ }^{l}$ and Paulo Ricardo Pezzuto ${ }^{2,3}$ \\ ${ }^{1}$ Instituto de Biociências da Universidade de São Paulo \\ Doutorado em Ecologia \\ (Rua do Matão, 321, 05508-900 São Paulo, SP, Brasil) \\ lialves@1ycos.com \\ ${ }^{2}$ Centro de Ciências Tecnológicas da Terra e do Mar - Universidade do Vale do Itajaí \\ (Rua Uruguai, 458, 88.302-202 Itajaí, SC, Brasil) \\ pezzuto@univali.br \\ ${ }^{3}$ Corresponding author
}

\section{A B S T R A C T}

The aim of this study was to determine the short-term environmental changes caused by the simultaneous passage of a high energy event on two sandy beaches with different morphodynamic states and their influence on the richness, abundance and distribution of the benthic macrofauna. Two microtidal exposed sandy beaches with contrasting morphodynamics were simultaneously sampled before, during and after the passage of two cold fronts in Santa Catarina. The reflective beach showed a higher susceptibility to the increase in wave energy produced by the passage of cold fronts and was characterized by rapid and intense erosive processes in addition to a capacity for rapid restoration of the beach profile. As regards the dissipative beach, erosive processes operated more slowly and progressively, and it was characterized further by a reduced capacity for the recovery of its sub-aerial profile. Although the intensity of the environmental changes was distinct as between the morphodynamic extremes, changes in the composition, richness and abundance of macrobenthos induced by cold fronts were not evident for either of the beaches studied. On the other hand, alterations in the distribution pattern of the macrofauna were observed on the two beaches and were related to variations in sea level, position of the swash zone and moisture gradient, suggesting that short-term accommodations in the spatial structure of the macrobenthos occur in response to changes in environmental conditions in accordance with the temporal dynamics characteristic of each morphodynamic state.

\section{RESUMO}

Com o objetivo de avaliar as alterações ambientais de curtoprazo causadas pela passagem de um mesmo evento de alta energia em praias com diferentes estágios morfodinâmicos e sua influência na riqueza, abundância e distribuição do macrobentos, duas praias arenosas expostas e pertencentes aos extremos morfodinâmicos foram simultaneamente amostradas antes, durante e após a passagem de duas frentes frias em Santa Catarina. A praia refletiva apresentou maior suscetibilidade ao incremento de onda causado pelos eventos e caracterizou-se por rápidos e intensos processos erosivos, além de apresentar uma rápida capacidade de restauração do perfil praial. Por outro lado, os processos erosivos operaram de forma lenta e progressiva na porção subaérea da praia dissipativa, que caracterizou-se por uma reduzida capacidade de recuperação do perfil . Embora a intensidade das alterações ambientais tenha sido distinta entre os extremos morfodinâmicos, mudanças na composição, riqueza e abundância do macrobentos, induzidos pelas frentes frias, não foram evidentes para nenhuma das praias estudadas. Por outro lado, alterações na distribuição da macrofauna foram verificadas nas duas praias e estiveram relacionadas com as variações do nível do mar, do posicionamento da zona de espraiamento e dos gradientes de umidade daí decorrentes, sugerindo que acomodações de curto prazo na estrutura espacial do macrobentos ocorrem como resposta às alterações nas condições ambientais de acordo com a dinâmica temporal característica de cada estágio morfodinâmico.

Descriptors: Natural disturbance, Sandy beaches, Cold fronts, Benthic macrofauna, Natural experiment, Brazil.

Descritores: Distúrbio natural, Praia arenosa, Frentes frias, Macrofauna bentônica, Experimento natural, Brasil. 


\section{INTRODUCTION}

Storms with their high levels of wave action present one of the greatest natural hazards to sandy beaches and may dramatically alter their physical and biological characteristics (AUBREY, 1983; BROWN, 1996; MCLACHLAN; BROWN, 2006). Erosive processes can occur as a result of this type of event, but the magnitude of these processes depends on the morphodynamic state of the beach (SHORT, 1999). That is, the wave energy necessary to induce erosion, as well as mechanisms that control each morphodynamic state, are distinct, which implies that the same wave climate acting on different morphodynamic conditions produces different responses in terms of morphological changes (WRIGHT; SHORT, 1984) .

Reflective beaches are more susceptible to higher waves and experience rapid and intense erosive processes. On this beach type, any elevation in wave energy can induce erosive processes in the sub-aerial profile, because of the direct dissipation of the wave energy on the beach face. On the other hand, a much greater amount of wave energy is necessary to induce erosion in the sub-aerial profile of dissipative beaches. These beaches are characterized by wide low gradient surf zones with multiple bars parallel to the shore that dissipate a substantial part of the wave energy before reaching the beach face (SHORT, 1999).

Wave action and sediment disturbance associated with storms may have a strong influence in species composition and abundance of benthic assemblages. These can result from both direct effects on survivorship of species and indirect effects such as changes in environmental characteristics (BROWN, 1996; POSEY et al., 1996). However, although there are records of massive mortality of benthic organisms on sandy beaches caused by storms (e.g., FITCH, 1950; MCLACHLAN et al., 1996), there are few studies dedicated to investigating the role of high energy events in structuring the macrofauna of this environment.

This type of study has been conducted by Crocker (1968) and Saloman and Naughton (1977), who examined the effect of hurricanes on the macrofauna of sandy beaches on the east coast of the United States. In Brazil, the only studies dealing with this subject were undertaken by Cochôa et al. (2006), who investigated the effect of a meteorological front on the distribution of macrobenthos on a dissipative beach in Paraná, by Sola and Paiva (2001) who evaluated the effect of two storm surges on the nearshore macrofauna of a sandy beach in Rio de Janeiro, and by Gallucci and Netto (2004) who examined the effects of two cold fronts on the macrofauna and meiofauna at a shallow sublittoral site off a sheltered beach in Santa Catarina. However, no studies to date have investigated the effect of the same high energy event on beaches with different morphodynamic states.

In Southern Brazil, the passage of cold fronts constitutes the meteorological disturbance responsible for most of the morphological changes observed on sandy beaches. The winds associated with this unpredictable natural event generate high energy waves which can induce intensive erosional processes on sandy beaches (CALLIARI et al., 1998; KLEIN; MENEZES, 2001). Consequently, the passage of cold fronts can, potentially, disturbs the benthic macrofauna and plays an important role in structuring the local sandy beach communities.

The aim of the present study was to investigate: a) the short-term effects of a same cold front on the physical and morphological characteristics of sandy beaches with contrasting morphodynamics in Santa Catarina; and b) the consequent changes in the composition, abundance and distribution pattern of the benthic macrofauna in the sub-aerial beach profile.

\section{Methods}

Study Area

Two microtidal sandy beaches located in the central-north coast of Santa Catarina State $\left(26^{\circ} 30^{\prime} \mathrm{S}\right.$ and $27^{\circ} 20$ 'S) were selected for this study (Fig. 1). These beaches are exposed to wave action and have a $\mathrm{N}-\mathrm{S}$ orientation but represent different morphodynamic types (KLEIN; MENEZES, 2001).

Taquaras is a reflective beach with moderately well sorted to well sorted coarse sands ( 0.72 to $0.92 \mathrm{~mm}$ ) with low moisture content. It is characterized by a steep slope profile $\left(10^{\circ}\right)$ and deep water table (KLEIN; MENEZES, 2001; ALVES et al., 2004). It has a parabolic plan form and its shoreline is $920 \mathrm{~m}$ long (KLEIN et al., 2002a). It is subject to high sediment mobility throughout the year and may present scarps of $2 \mathrm{~m}$ height during storm events associated with cold fronts (KLEIN; MENEZES, 2001).

In contrast, Navegantes is a dissipative beach with well sorted fine sands $(0.15$ to $0.19 \mathrm{~mm})$ and gentle slope $\left(2.5\right.$ to $\left.3.5^{\circ}\right)$, subjected to low to moderate sediment mobility during the year (KLEIN; MENEZES, 2001). It is characterized by high moisture content along the beach profile, associated with a superficial water table (ALVES et al., 2004). It has very highly developed frontal dunes, a surf zone of between 54 and $83 \mathrm{~m}$ wide with a multiple-bar system and a shoreline of $10,030 \mathrm{~m}$ in length (KLEIN; MENEZES, 2001). The Itajaí-açu River flows into the sea at the southern extremity of the beach, influencing 
coastal water salinity that varies from 22 to 36 (SCHETTINI, 2002; ALVES et al., 2004). Because of their distinctive environmental characteristics, these beaches' richness and abundance of benthic macrofauna differ markedly. Taquaras presents a reduced number of species (9), almost exclusively crustaceans. The isopod Excirolana braziliensis is the most abundant species $\left(156.2\right.$ org. $\mathrm{m}^{-2}$ ) and represents $81 \%$ of the total density of macrofauna. Emerita brasiliensis (24.5 org. $\left.\mathrm{m}^{-2}\right)$ and Atlantorchestoidea brasiliensis $\left(4.9\right.$ org. $\mathrm{m}^{-2}$ ) represent 14 and $2.7 \%$ of the total macrofauna of this beach, respectively. On the other hand, Navegantes harbors a greater number of species (18) and is dominated numerically by the polychaetes Scolelepis sp. (307.3 org. $\left.\mathrm{m}^{-2}\right)$ and Euzonus furciferus (139.7 org. $\mathrm{m}^{-2}$ ) and by the bivalve Donax hanleyanus (105.5 org. $\mathrm{m}^{-2}$ ). Together, these three species represent $79.8 \%$ of the total macrofauna of this beach (ALVES 2004).

The local tides are semidiurnal with a mean range of $0.8 \mathrm{~m}$ and a maximum range of $1.2 \mathrm{~m}$. Moreover, meteorological tides play an important role on the sea level because storm surges can raise it at least $1 \mathrm{~m}$ above the astronomical tide (SCHETTINI et al., 1999). Due to the temperate climate that characterizes the region (NOBRE et al., 1986), the sea water temperature presents a marked seasonality, with the lowest values $\left(14\right.$ to $\left.16^{\circ} \mathrm{C}\right)$ occurring in winter and the highest ones $\left(24\right.$ to $29.5^{\circ} \mathrm{C}$ ) in summer (ALVES, E. S., 2004).

Northeasterly winds predominate throughout the year, but this pattern is frequently disturbed by the cold fronts that typically move along the coast from SW to NE, with higher intensity and frequency in austral Winter and Spring. The passage of these frontal systems is accompanied by the migration of high and low pressure centers which disturb the basic air flow, producing significant winds and waves from the South and East quadrants (NOBRE et al., 1986; ALVES; MELO, 2001). These winds are usually associated with precipitation and, as cited above, produce high energy waves which can induce intense morphological changes on Southern Brazilian sandy beaches (CALLIARI et al., 1998; KLEIN; MENEZES, 2001).

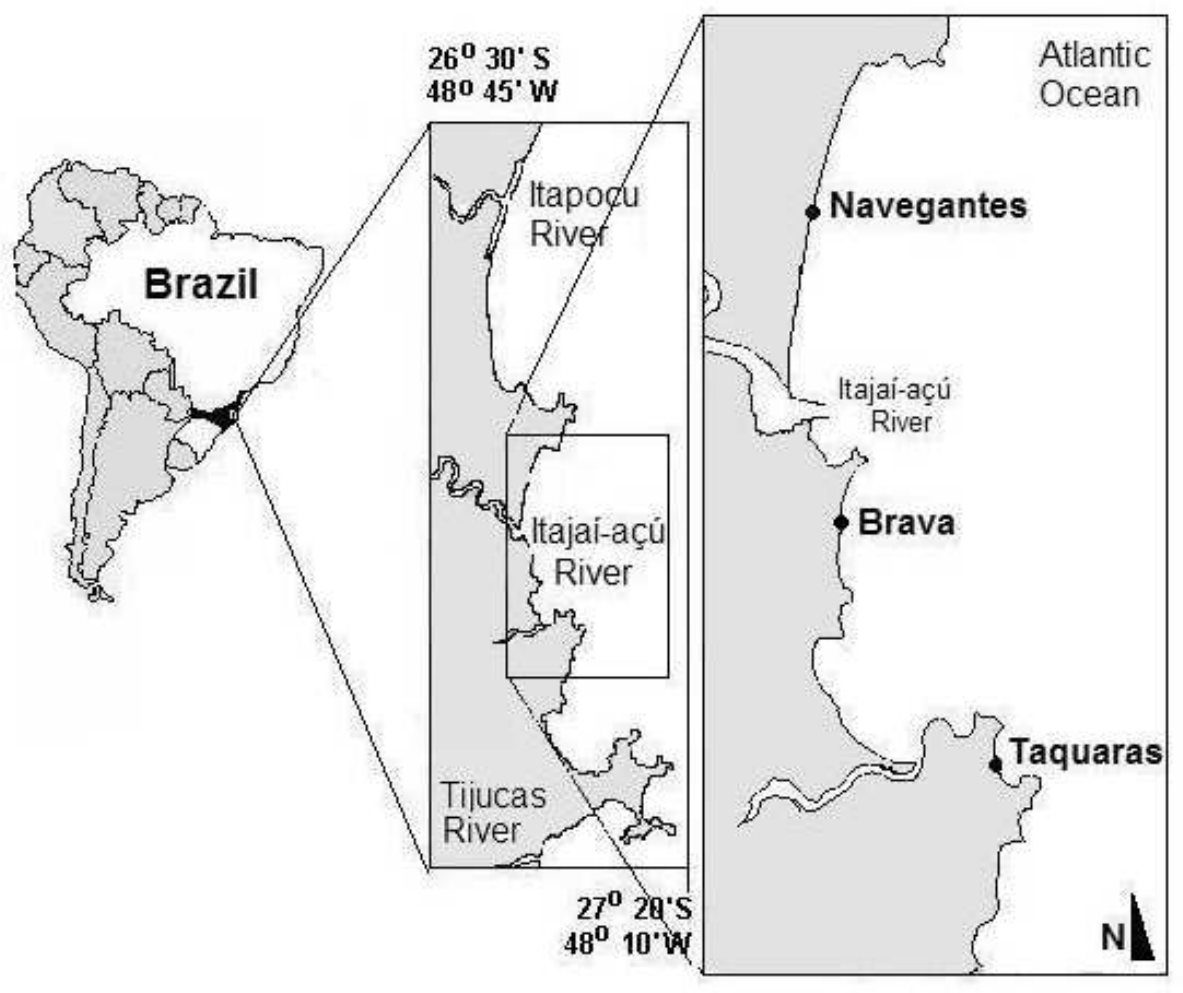

Fig. 1. Study area and location of the sampling sites. 
The average significant height of locally generated waves (from an E-NE direction) is $0.75 \mathrm{~m}$ with a peak period of from 3 to $8 \mathrm{~s}$, but much higher waves can occur during the storms associated with cold fronts. South-southeast waves are the most severe in terms of significant wave heights ranging from 1 to $3.5 \mathrm{~m}$ and peak periods of from 4 to $8 \mathrm{~s}$, and are generated by winds caused by low-pressure systems carried along the coast by cold fronts (ALVES; MELO, 2001). Based on visual wave observations conducted during 238 consecutive days, Klein et al. (2002) observed that the average wave height in the surf zone of a local exposed sandy beach was $0.8 \mathrm{~m}$, but that it reached $1.8 \mathrm{~m}$ during storms associated with cold fronts.

\section{Sampling and Laboratory Procedures}

Collections were undertaken before, during and after two cold fronts that occurred, respectively, on August 17-22 and September 10-12, 2002 (Fig. 2). These events were identified by daily monitoring conducted between March and September, 2002, utilizing satellite images and numerical prediction models for weather and waves generated by the Instituto Nacional de Pesquisas Espaciais (INPE) and

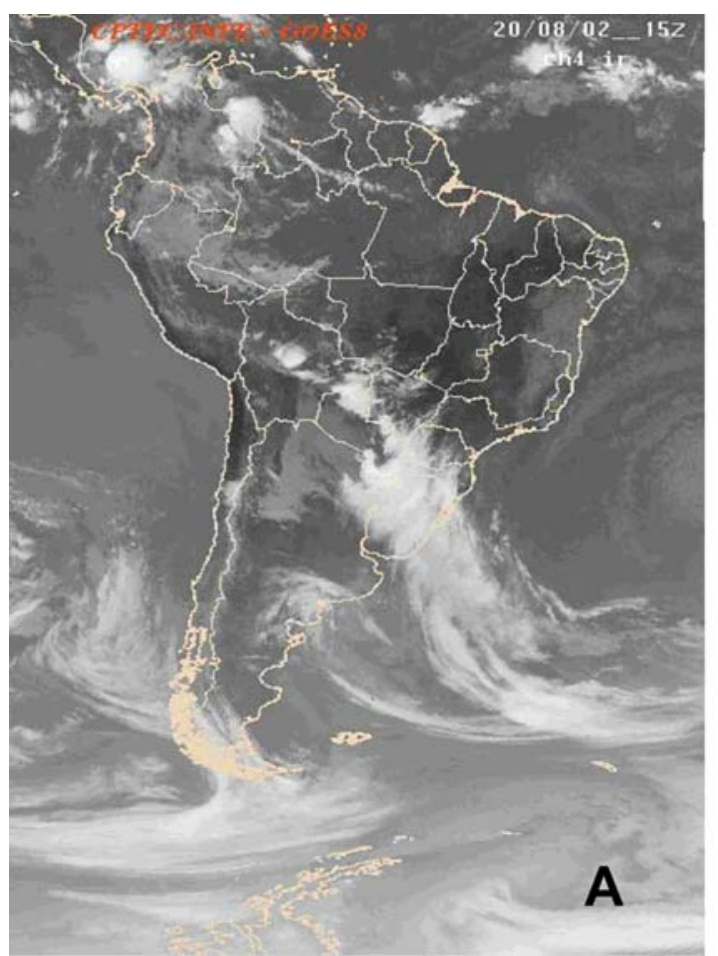

made available through its internet web site (www.cptec.inpe.br).

Because the aim of the present study was to compare the responses of beaches with different morphodynamic characteristics to the same incident wave energy, samplings were performed simultaneously at the two beaches during each cold front, according to the following scheme.

a) Prior sampling: two samplings were carried out on days immediately preceding the passage of the cold front. The purpose of these samples was to characterize the initial condition of the beaches and establish their natural short-term variability in the absence of the cold front disturbance, in order to identify the effects caused specifically by this type of event. These samples were, thus, used as controls.

b) Sampling during the disturbance: these samplings were carried out during the passage of the cold fronts to determine the immediate alterations caused by the disturbance.

c) Subsequent sampling: these samplings were carried out on consecutive days immediately after the passage of the cold fronts to evaluate the changes that had occurred on the beaches during the transition between the disturbance and the subsequent return to a calm condition.

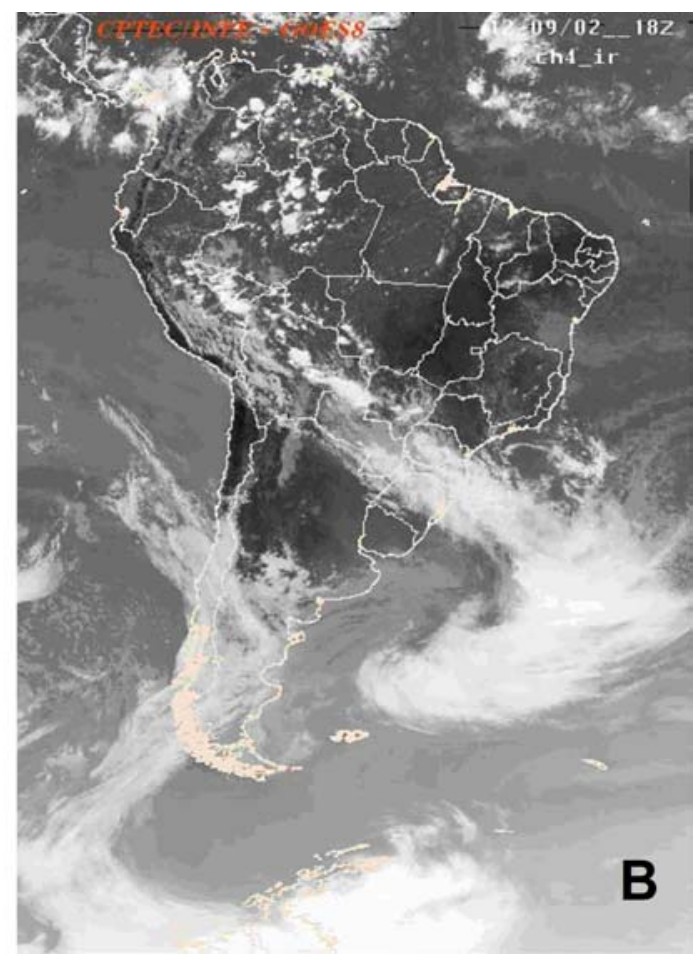

Fig. 2. Satellite image of cold fronts monitored in August (A) and September (B) in Santa Catarina. 
However, due to operational problems related to this type of study, the number and frequency of sampling varied between the events, as described below:

- Event of August, 2002: two prior samplings were conducted three weeks before the passage of the cold front, one on each of two consecutive days (July 26 and 27). After the establishment of the high energy system, which began on August 17, samplings were performed every two days, one collection being made during the disturbance (August 20) and two afterwards (August 22 and 24). Actually, the sampling of August 22 coincided with the initial weakening of the storm. Due to the sampling frequency adopted, the condition of the beach immediately before the cold front was not determined on this occasion. On the other hand, it was possible to evaluate the beach's return to the calm condition, since this was maintained until the establishment of the event of September, 2002.

- Event of September, 2002: two prior samplings were conducted (September 5-7), three days before the passage of cold front, which made it possible to evaluate the condition of the beaches immediately before the disturbance. Two other samplings were carried out at intervals of approximately two days: the first on the day corresponding to the initial formation of the high energy system (September 10) and the second after the complete establishment of the event (September 12 and 13, for Taquaras and Navegantes, respectively). It should be noted that the samplings could not be carried out simultaneously at the two beaches during this event. It was only possible, therefore, at Navegantes to take samples during the onset of the storm and a day after its weakening. Although the results should be interpreted with caution, the fact that the samples were taken at distinct times within the same event does not invalidate the comparison between the beaches. The reason for this is that the sub-aerial portion of dissipative beaches is known to respond more slowly to alterations caused by an increase in wave energy (see Results). Due to adverse weather conditions, samplings were not taken during the exact peak of the cold fronts of either of the events. All samplings were performed on transects located in the central part of each beach (Fig. 1) to reduce the possible influence of rocky promontories and/or other physical obstacles present at the extremities of the beaches on their hydrodynamic and morphodynamic conditions. Sampling stations were demarcated on each transect at $5 \mathrm{~m}$ intervals, from the dunes to the lower limit of the swash zone. The upper limit of the transects on each beach was determined from a fixed reference point (Fig. 3) to maintain the spatial correspondence between the stations at all sampling times.

Five $0.03 \mathrm{~m}^{2}$ replicates were taken randomly at each station with a plastic cylinder, to $20 \mathrm{~cm}$ depth, in an area of $5 \times 12 \mathrm{~m}$. The sediment retained in each sample was sieved through a $0.5 \mathrm{~mm}$ mesh and fixed in formaldehyde $4 \%$. The animals were identified and counted in the laboratory. Ten quadrats of $2.25 \mathrm{~m}^{2}$ were randomly taken at each station for counting Ocypode quadrata burrows.

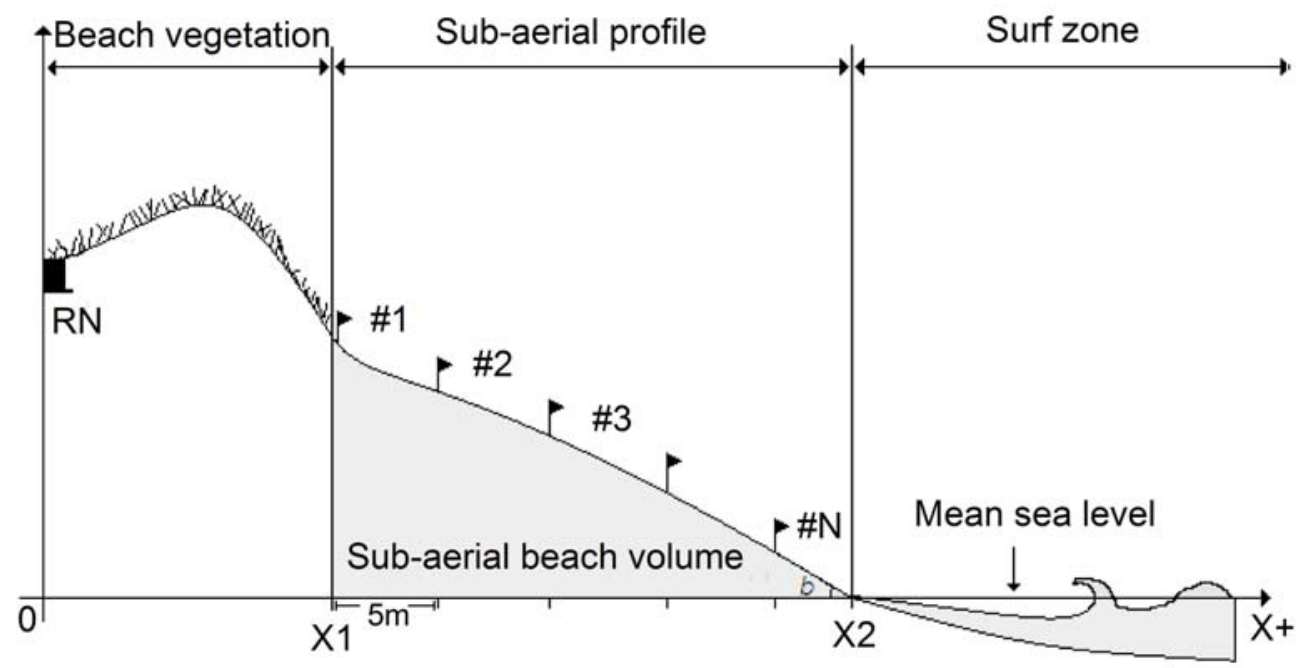

Fig. 3. Sampling scheme. RN: fixed reference point; \#- sampling station; X1: landward boundary corresponding to the first sampling station. Landward boundary is constant per profile and its location was determined from RN; X2: seaward boundary during spring low tides; b: beach slope. 
The following abiotic factors were monitored at all sampling times: temperature and sea water salinity, surf zone width, wave height and period, beach morphology, moisture level of the sediment, and position of the swash zone and drift line.

Wave height was estimated visually measuring the difference in height between crest and trough at the moment immediately before its breaking. This procedure was performed during a period of approximately $5 \mathrm{~min}$ to obtain a mean value, which was calculated based on $1 / 3$ of the highest waves (significant wave height). Wave period was determined with a chronometer and corresponded to $1 / 10$ th of the total time it took for eleven consecutive crests to pass a fixed point in the surf zone. This procedure was carried out three times to obtain a mean value.

Beach morphology was determined by the method described by Birkemeier (1981). To permit the comparison between consecutive profiles, all surveys were taken based on a fixed reference point located at the base of the dunes on each beach (RN) (Fig. 3).

Three replicates were obtained at each sampling station with a $4 \mathrm{~cm}$ diameter corer taken to a depth of $5 \mathrm{~cm}$ for sediment moisture level determination. Samples were immediately weighed after the sampling and the moisture level (or water content of the sediment) was estimated by the weight loss of the sediment after drying at $50^{\circ} \mathrm{C}$ until the weight of the sample stabilized.

With the aim of relating the pattern of spatial distribution of the macrofauna to the physical limits imposed by the swash, the position of the drift line (corresponding to the upper limit of the last high tide) and of the lower and upper limits of the swash zone were determined at each sampling time, by measuring their distance in meters from the beginning of the beach profile (X1) (Fig. 3).

Monthly sampling was carried out during the previous year (March/2000 - March/2001) at Taquaras and Navegantes in order to evaluate the annual variability of the benthic macrofauna (ALVES, 2004) and to enable comparisons with the short-term variability caused by the passage of the cold fronts.

\section{Data Analysis}

The short-term effect of cold fronts on the abundance of benthic macrofauna was evaluated for the total number of organisms and for each species separately, at each of the beaches studied, using oneway analysis of variance (ANOVA). When present, significant differences among the treatments (sampling dates) were identified by Tukey's post-hoc test (ZAR, 1996). The analyses were carried out separately for the two events as: a) differences in their characteristics, in terms of duration, intensity and effects on environmental factors (see Results), could affect the macrofauna in different ways; b) possible dependence between events, in terms of cumulative effects, would affect the sampling controls of the second event and/or change the macrofauna's susceptibility to it; c) the experiment was not balanced, as the samplings (before, during and after) were not carried out at regular time intervals and numbers between events, which would lead to the comparison of distinct situations for each event; d) the time elapsed between the control samplings related to the first event and the last one related to the second event was of nearly 60 days. Thus, grouping the events could lead the objective of testing the short-term response of the fauna astray if it was masked by other processes inducing monthly variability in the community. The data for Puelche sp. and Euzonus furciferus were transformed by $\log _{10}(x+1)$ to comply with the requirements of normality and homogeneity of variances demanded by the analysis. Species with a frequency of less than $25 \%$ (considering the two events) were excluded from the analyses. The level of significance adopted was $5 \%$.

The abundance data was expressed per running meter or strip transect as suggested by Defeo (1996) and were calculated according to the following equation (BRAZEIRO; DEFEO, 1996):

$$
I S T=\frac{\sum_{i=1}^{n} q_{i}}{n} w
$$

where $I S T$ is the number of individuals per running meter of beach, $q$ the mean density (org. $\mathrm{m}^{-2}$ ) at each sampling station $(i), n$ the total number of samples pertaining to the transect, and $w$ the total length of the transect (in meters).

The effect of cold fronts on the zonation of benthic macrofauna was determined for each beach by comparing kite diagrams constructed for each date, based on the mean densities of the species, obtained at each sampling station.

The identification of zones for each beach was carried out for all the sampling dates by cluster analysis ( $Q$ mode). The dissimilarity among the different sampling stations was estimated by the BrayCurtis coefficient, using the $4^{\text {th }}$ root-transformed mean abundance of species at each sampling station. Dendrograms were constructed by the mean linkage method (UPGMA) (LEGENDRE; LEGENDRE, 1998) and a level of dissimilarity of 0.5 was adopted for the definition of groups. Groups of stations (or individual stations) showing reduced densities of particular species were not considered as a zone per se. All species collected were taken into consideration in these analyses. The zones, corresponding to each beach, were identified by letters ( $\mathrm{N}$ for Navegantes and $\mathrm{T}$ for Taquaras) and by numbers, indicating their sequential position between the dunes and the sea. 


\section{RESUltS}

\section{Environmental Characterization}

Despite the absence of data for the energy peaks, it was possible to observe that the passage of the cold fronts was characterized by marked changes in the hydrodynamic conditions of the beaches, represented by the widening of the surf zone and an increase in wave height and period (Table 1). At the two beaches, the incident wave height peaked during the cold fronts and decrease afterwards. The wave period showed a similar pattern, but remained high after the weakening of the event recorded in August. At Taquaras, the lower swash limit and the drift line moved up the beach during both cold fronts (Fig. 4A). At Navegantes, displacements to upper levels were observed for the lower and upper swash limit and were evident only during the second event (Fig. 4B). No temporal variations in sea water temperature or salinity as a result of the cold fronts were observed for either of the beaches (Table 1).

The same cold front led to different responses in terms of sediment remobilization on the beaches studied. Taquaras showed greater susceptibility to the increase in wave height. Rapid and intense morphological changes were observed at the middle and lower levels of this beach during the high energy events, when sedimentary sections of more than $1 \mathrm{~m}$ deep were removed (Fig. 5). The greater intensity of erosive processes was accompanied also by a fast recovery of its beach profile. During the weakening of the first event on August 22, an intense accretion (of more than $50 \mathrm{~cm}$ ) was observed to the sub-aerial beach profile, permitting its restoration within a few days.

Table 1. Surf zone parameters obtained during the period from July to September, 2002 on Taquaras and Navegantes beaches. SZW: surf zone width; NBL: number of breaker lines; DBL: distance between breaker lines and water line; Hs: significant wave height; Hmax: maximum wave height; T: wave period; S: seawater salinity; T: seawater temperature. Dates in bold type represent the cold front situations.

Taquaras

\begin{tabular}{lccccccccc}
\hline Date & Jul 26 & Jul 27 & Aug 20 & Aug 22 & Aug 24 & Sep 5 & Sep 7 & Sep 10 & Sep 12 \\
SZW $(m)$ & 0 & 0 & 15 & 7 & 0 & 0 & 0 & 0 & 40 \\
NBL & 1 & 1 & 1 & 1 & 1 & 1 & 1 & 1 & 1 \\
DBL (m) & 0 & 0 & 15 & 7 & 0 & 0 & 0 & 0 & 40 \\
Hs $(m)$ & 0.9 & 0.8 & 1.5 & 1.1 & 1.1 & 0.6 & 1.2 & 1.8 & 1.8 \\
Hmax (m) & 1.1 & 1.0 & 2.0 & 1.5 & 1.4 & 0.9 & 1.6 & 2.1 & 2.5 \\
$\mathrm{~T}(\mathrm{~s})$ & 9.2 & 8.0 & 8.6 & 10.9 & 11.6 & 4.6 & 8.1 & 8.9 & 9.3 \\
$\mathrm{~S}(\% \circ)$ & 33 & 33 & 32 & 32 & 30 & 32 & 33 & 33 & 34 \\
$\mathrm{~T}\left({ }^{\circ} \mathrm{C}\right)$ & 19 & 19 & 19 & 19 & 20 & 19 & 19 & 20 & 20 \\
\hline
\end{tabular}

Navegantes

\begin{tabular}{lccccccccc}
\hline Date & Jul 26 & Jul 27 & Aug 20 & Aug 22 & Aug 24 & Sep 6 & Sep 7 & Sep 10 & Sep 13 \\
SZW (m) & 30 & 30 & 80 & 100 & 80 & 60 & 80 & 100 & 100 \\
NBL & 1 & 1 & 2 & 2 & 2 & 1 & 2 & 2 & 2 \\
DBL (m) & 30 & 30 & $20 / 80$ & $20 / 100$ & $50 / 80$ & 60 & $30 / 80$ & $30 / 100$ & $40 / 100$ \\
Hs (m) & 0.6 & 0.7 & 1.4 & 1.2 & 0.7 & 0.8 & 0.9 & 1.6 & 1.0 \\
Hmax (m) & 0.8 & 0.9 & 1.8 & 1.5 & 0.9 & 1.0 & 1.1 & 2.5 & 1.2 \\
T (s) & 6.6 & 7.9 & 9.9 & 9.7 & 9.9 & 5.6 & 5.7 & 10.5 & 9.8 \\
$\mathrm{~S}\left(\%_{\mathrm{o}}\right)$ & 33 & 33 & 30 & 28 & 28 & 33 & 33 & 32 & 32 \\
$\mathrm{~T}\left({ }^{\circ} \mathrm{C}\right)$ & 19 & 19 & 20 & 19 & 21 & 19 & 20 & 20 & 20 \\
\hline
\end{tabular}



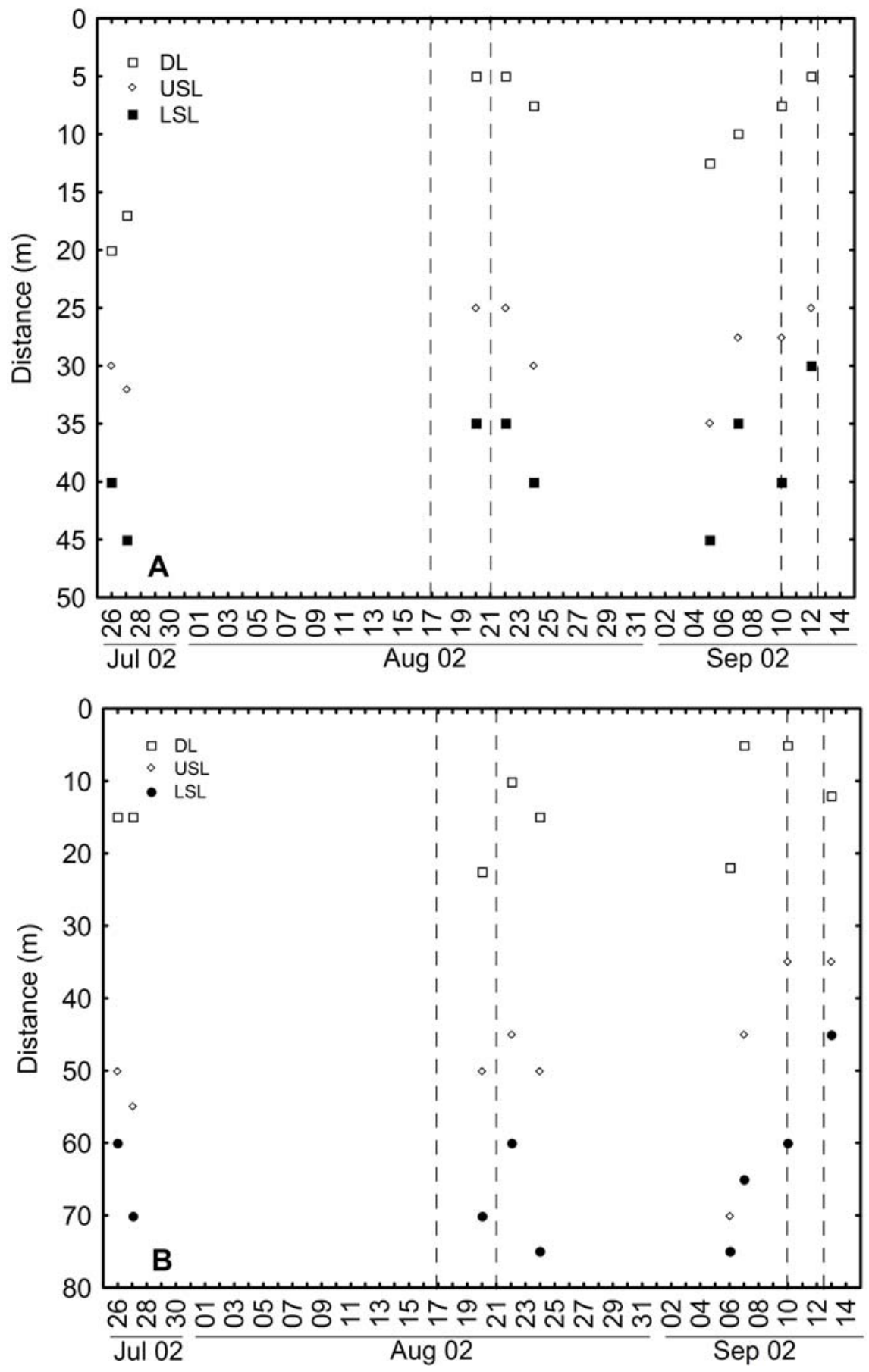

Fig. 4. Position of driftline (DL) and upper (USL) and lower limits (LSL) of swash zone recorded between July 26 and September 13 of 2002 on Taquaras (A) and Navegantes (B) beaches. Dotted lines indicate the high energy events. 

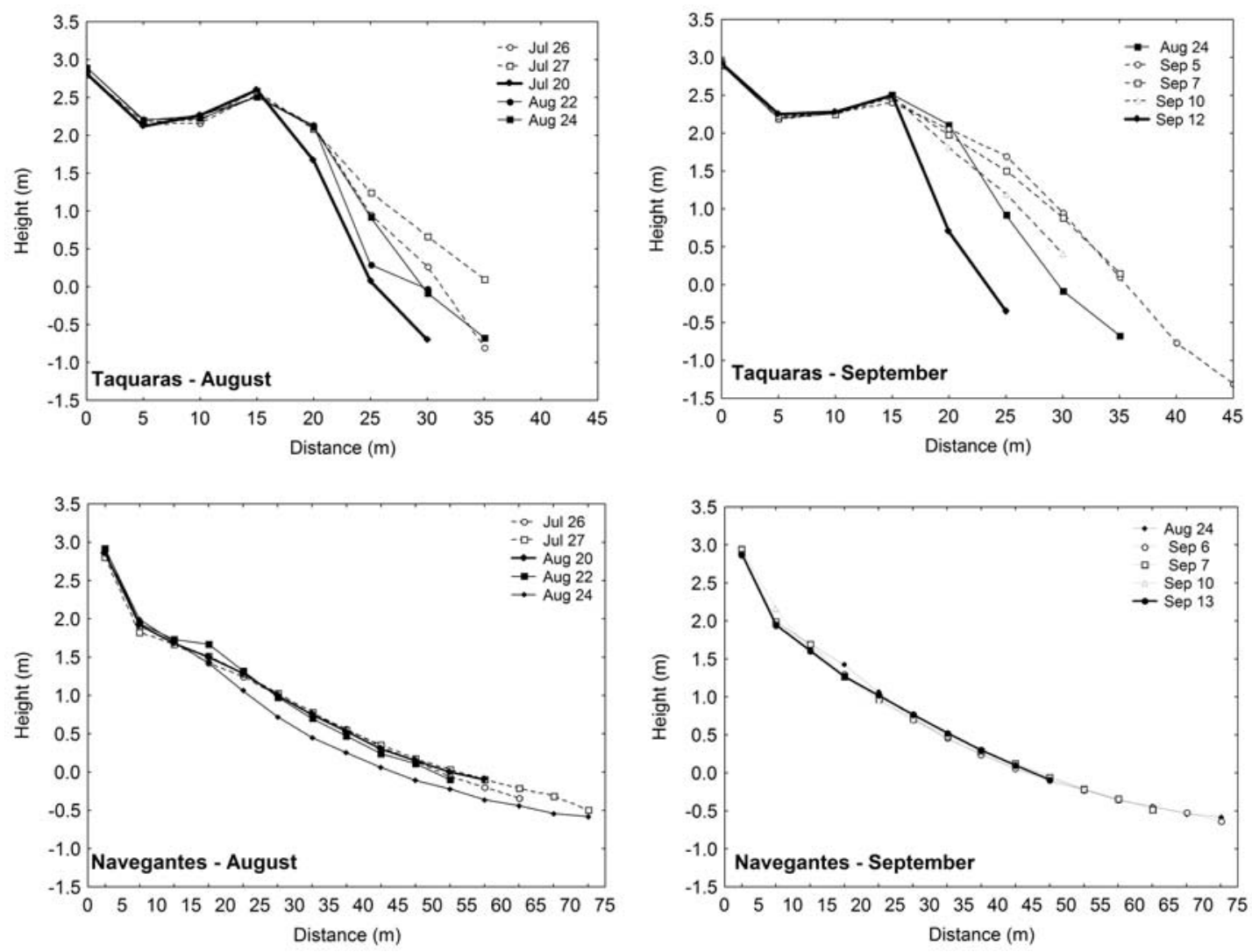

Fig. 5. Subaerial beach morphology recorded during August and September high energy events on Taquaras and Navegantes beaches.

Conversely, Navegantes was characterized by reduced morphological changes during the cold fronts (Fig. 5). Vertical sediment remobilization over the profile did not exceed $30 \mathrm{~cm}$ and was only registered during the August event. On that occasion, most of the erosion occurred between August 22 and 24, two days after the passage of the peak of the high-energy system, and no restoration of the sub-aerial profile was observed by the end of the study. Conversely to what was observed at Taquaras, the magnitude of sediment remobilization at Navegantes was similar on the various levels of the beach.

Changes in the moisture gradient, induced by the cold fronts, were recorded only for Taquaras (Fig. 6). High sediment moisture levels occurred on this beach only in the swash zone. Therefore, the rise in the sea level observed during the two cold fronts, resulted in a progressive increase in sediment moisture content at the upper levels. Conversely, no changes in moisture content were observed during either cold fronts at Navegantes (Fig. 6). However, it should be noted that an increase in sediment moisture was observed in September on the intermediate levels of this beach (between 10 and $20 \mathrm{~m}$ ) as compared to August. The erosion induced by the first cold front on this beach, resulting in the removal of a $30 \mathrm{~cm}$ sediment layer (Fig. 5), may have contributed to the emergence of the water table and to the higher sediment moisture content observed at these levels in September (Fig. 6).

\section{Benthic Macrofauna \\ Composition and Abundance}

In general, the environmental changes resulting from the passage of the cold fronts do not appear to have caused pronounced variations in the composition or abundance of the benthic macrofauna on the two beaches studied.

A total of five species were found at Taquaras between July and September, 2002, and varied from 3 to 4 on each sampling date (Table 2). With the exception of the bivalve Donax hanleyanus, only 
crustaceans were recorded on this beach. The isopod Excirolana braziliensis dominated the fauna numerically, representing, on average, $88.6 \%$ of the total organisms collected (Table 2). On this beach, the intense beach erosion observed during the first event monitored had no negative effect on the macrofauna abundance (Fig. 7). On the other hand, a significant increase in the abundance of $E$. braziliensis was found on August 22 (Table 3) as the high energy system began to weaken. On August 24 this species again attained the same levels of abundance registered before the passage of the cold front and sustained them until the end of the September event (Fig. 7B). Similar results were recorded for the total abundance of the macrofauna (Table 3 and Fig. 7E), reflecting the same pattern observed for E. braziliensis.

Significant changes in total abundance of the macrofauna at Taquaras were also observed during the September event (Table 3). However, these differences did not result specifically from the effects of the cold front, since they were recorded prior to the establishment of the high-energy system (Fig. 7E). No
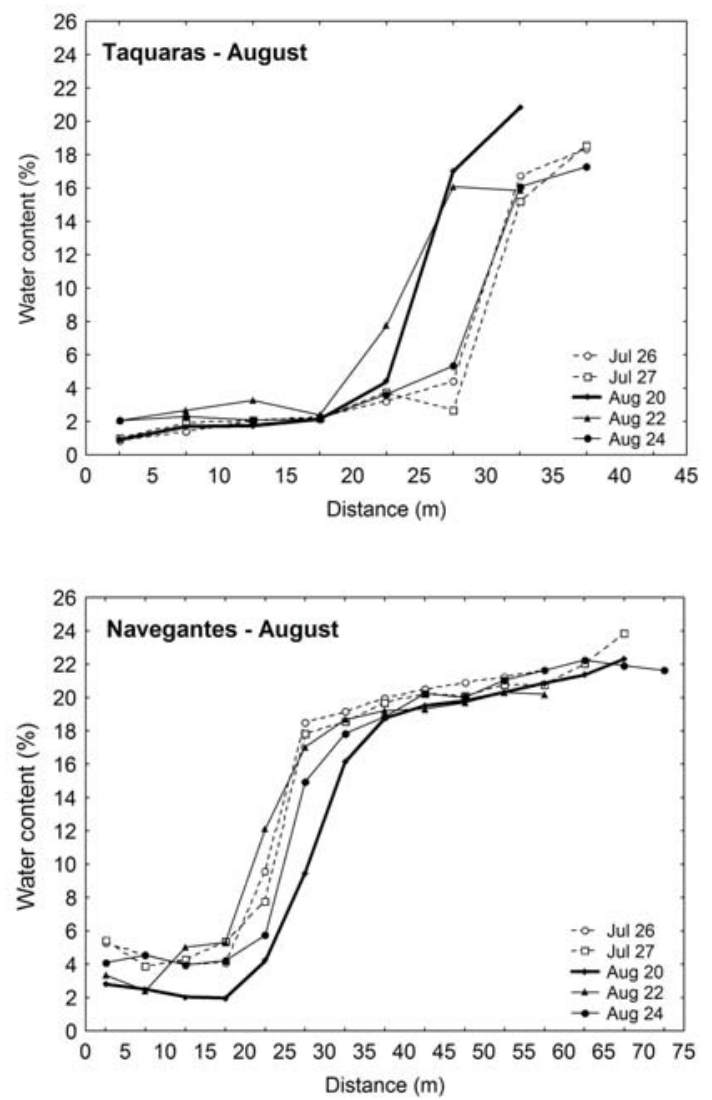

significant differences were detected for any particular species during this event (Table 3 ).

At Navegantes, a total of 17 species were recorded between July and September, 2002. Temporal variability in the richness (13 to 16 species) was mainly related, in this period, to the occurrence of organisms with distribution in the lower midlittoral and/or infralittoral. The polychaetes Scolelepis sp. and Euzonus furciferus dominated the fauna numerically, contributing respectively with $69 \%$ and $18.7 \%$ of the total macrofauna of this beach (Table 2). No significant difference was found in total abundance of the macrofauna at Navegantes in either event. Only the species Ocypode quadrata, Puelche sp., Phoxocephalopsis zimeri, Bowmaniella brasiliensis and Donax gemmula showed significant changes in their mean abundance (Table 4). However, except for $O$. quadrata, whose abundance was significantly higher during the two cold fronts, the other species did not show any consistent response in relation to the high-energy events (Fig. 8).
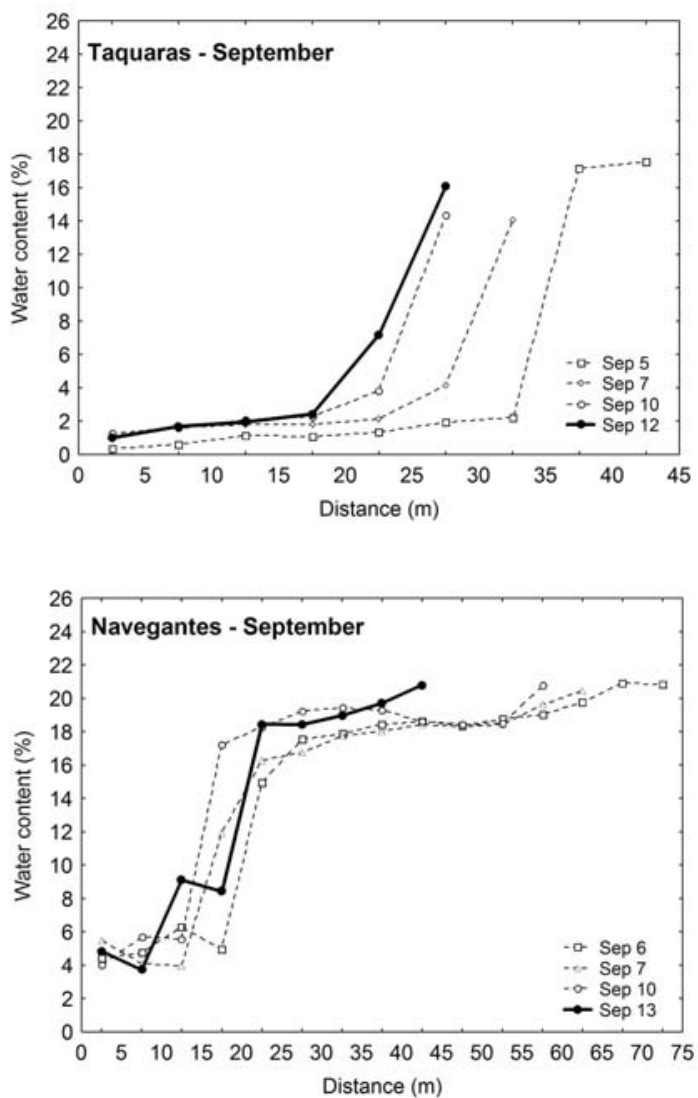

Fig. 6. Water content of sediment recorded during August and September high energy events on different levels of subaerial profile at Taquaras and Navegantes beaches. 
Table 2. Numerical importance (\%) and frequency of occurrence (\%) of the species recorded during the period from July to September, 2002 on Taquaras and Navegantes beaches. Mean: mean of the numerical importance; f.o.: frequency of occurrence. Dates in bold type represent the high energy events.

\begin{tabular}{|c|c|c|c|c|c|c|c|c|c|c|c|}
\hline \multirow{2}{*}{ Species } & \multicolumn{11}{|c|}{ Taquaras } \\
\hline & $7 / 26$ & $7 / 27$ & $8 / 20$ & $8 / 22$ & $8 / 24$ & $9 / 5$ & $9 / 7$ & $9 / 10$ & $9 / 12$ & mean & f.o. \\
\hline Excirolana braziliensis & 91.1 & 80.7 & 80.4 & 91.3 & 85.2 & 87.9 & 96.4 & 93.9 & 90.8 & 88.6 & 100 \\
\hline Emerita brasiliensis & 15.7 & 15.0 & 16.6 & 7.3 & 12.8 & 9.6 & 1.6 & 5.7 & 8.7 & 10.3 & 100 \\
\hline Donax hanleyanus & 2.0 & 3.5 & 2.6 & 1.2 & 0.0 & 2.1 & 0.0 & 0.0 & 0.0 & 1.3 & 55 \\
\hline Ocypode quadrata & 0.4 & 0.8 & 0.4 & 0.2 & 0.6 & 0.4 & 0.5 & 0.3 & 0.5 & 0.5 & 100 \\
\hline Tylos niveus & 0.0 & 0.0 & 0.0 & 0.0 & 1.4 & 0.0 & 1.6 & 0.0 & 0.0 & 0.3 & 22 \\
\hline \multirow[t]{3}{*}{ Total of species } & 4 & 4 & 4 & 4 & 4 & 4 & 4 & 3 & 3 & & \\
\hline & \multicolumn{11}{|c|}{ Navegantes } \\
\hline & $7 / 26$ & $7 / 27$ & $8 / 20$ & $8 / 22$ & $8 / 24$ & $9 / 6$ & $9 / 7$ & $9 / 10$ & $9 / 13$ & mean & f.o. \\
\hline Scolelepis sp. & 67.8 & 65.5 & 68.9 & 71.8 & 69.4 & 67.3 & 66.6 & 75.2 & 68.4 & 69.0 & 100 \\
\hline Euzonus furciferus & 22.6 & 23.5 & 16.9 & 17.8 & 17.8 & 17.7 & 19.3 & 10.9 & 20.0 & 18.7 & 100 \\
\hline Donax hanleyanus & 4.8 & 5.3 & 9.3 & 7.7 & 6.1 & 4.9 & 4.5 & 5.5 & 7.3 & 6.3 & 100 \\
\hline Puelche sp. & 0.5 & 1.1 & 1.9 & 1.1 & 2.7 & 4.4 & 4.3 & 1.6 & 1.6 & 2.1 & 100 \\
\hline Phoxocephalopsis zimeri & 0.1 & 0.3 & 0.7 & 1.2 & 1.6 & 2.8 & 2.3 & 3.4 & 0.4 & 1.4 & 100 \\
\hline Excirolana braziliensis & 0.5 & 0.3 & 0.8 & 0.7 & 0.7 & 0.5 & 0.7 & 0.7 & 0.7 & 0.6 & 100 \\
\hline Excirolana armata & 0.5 & 0.5 & 0.5 & 0.3 & 0.2 & 0.2 & 0.3 & 0.4 & 0.3 & 0.3 & 100 \\
\hline Donax gemmula & 0.1 & 0.1 & 0.0 & 0.0 & 0.8 & 1.3 & 0.2 & 0.2 & 0.0 & 0.3 & 67 \\
\hline Macrochiridothea giambiageae & 0.00 & 0.03 & 0.10 & 0.31 & 0.19 & 0.11 & 0.45 & 0.43 & 0.51 & 0.24 & 89 \\
\hline Bowmaniella brasiliensis & 0.08 & 0.65 & 0.03 & 0.00 & 0.29 & 0.32 & 0.45 & 0.00 & 0.09 & 0.21 & 78 \\
\hline Lepidopa richmondi & 0.20 & 0.16 & 0.24 & 0.17 & 0.45 & 0.14 & 0.08 & 0.33 & 0.14 & 0.21 & 100 \\
\hline Emerita brasiliensis & 0.12 & 0.03 & 0.17 & 0.20 & 0.13 & 0.11 & 0.50 & 0.33 & 0.28 & 0.21 & 100 \\
\hline Bathyporeiapus ruffoi & 0.04 & 0.00 & 0.28 & 0.20 & 0.23 & 0.11 & 0.21 & 0.05 & 0.19 & 0.14 & 89 \\
\hline Ocypode quadrata & 0.06 & 0.04 & 0.08 & 0.02 & 0.03 & 0.02 & 0.01 & 0.02 & 0.06 & 0.04 & 100 \\
\hline Atlantorchestoidea brasiliensis & 0.04 & 0.03 & 0.03 & 0.03 & 0.03 & 0.00 & 0.00 & 0.05 & 0.05 & 0.03 & 78 \\
\hline Sigalion cirriferum & 0.00 & 0.00 & 0.00 & 0.00 & 0.00 & 0.04 & 0.00 & 0.00 & 0.00 & 0.01 & 11 \\
\hline Austinixa patagoniensis & 0.00 & 0.00 & 0.00 & 0.00 & 0.03 & 0.00 & 0.00 & 0.00 & 0.00 & 0.01 & 11 \\
\hline Total of species & 14 & 14 & 14 & 13 & 16 & 15 & 13 & 14 & 14 & & \\
\hline
\end{tabular}

Table 3. Results of the ANOVAs conducted for the species collected during the high energy events of August (26/7 to 24/8) and September (5/9 to 12/9) 2002, on Taquaras beach. DF: degrees of freedom.

\begin{tabular}{lrrrrrrr}
\hline \multirow{2}{*}{ Species } & \multicolumn{3}{c}{ August/2002 } & & \multicolumn{2}{c}{ September/2002 } \\
\cline { 2 - 7 } & & DF & F & p & DF & F & p \\
\hline Ocypode quadrata & 4 & 0.90 & 0.48 & 3 & 1.99 & 0.16 \\
Excirolana braziliensis & 4 & 3.64 & $\mathbf{0 . 0 2}$ & 3 & 2.40 & 0.11 \\
Emerita brasiliensis & 4 & 0.49 & 0.74 & 3 & 1.82 & 0.18 \\
Donax hanleyanus & 4 & 0.68 & 0.61 & - & - & - \\
\hline Total & 4 & 3.43 & $\mathbf{0 . 0 3}$ & 3 & 3.67 & $\mathbf{0 . 0 3}$ \\
\hline
\end{tabular}



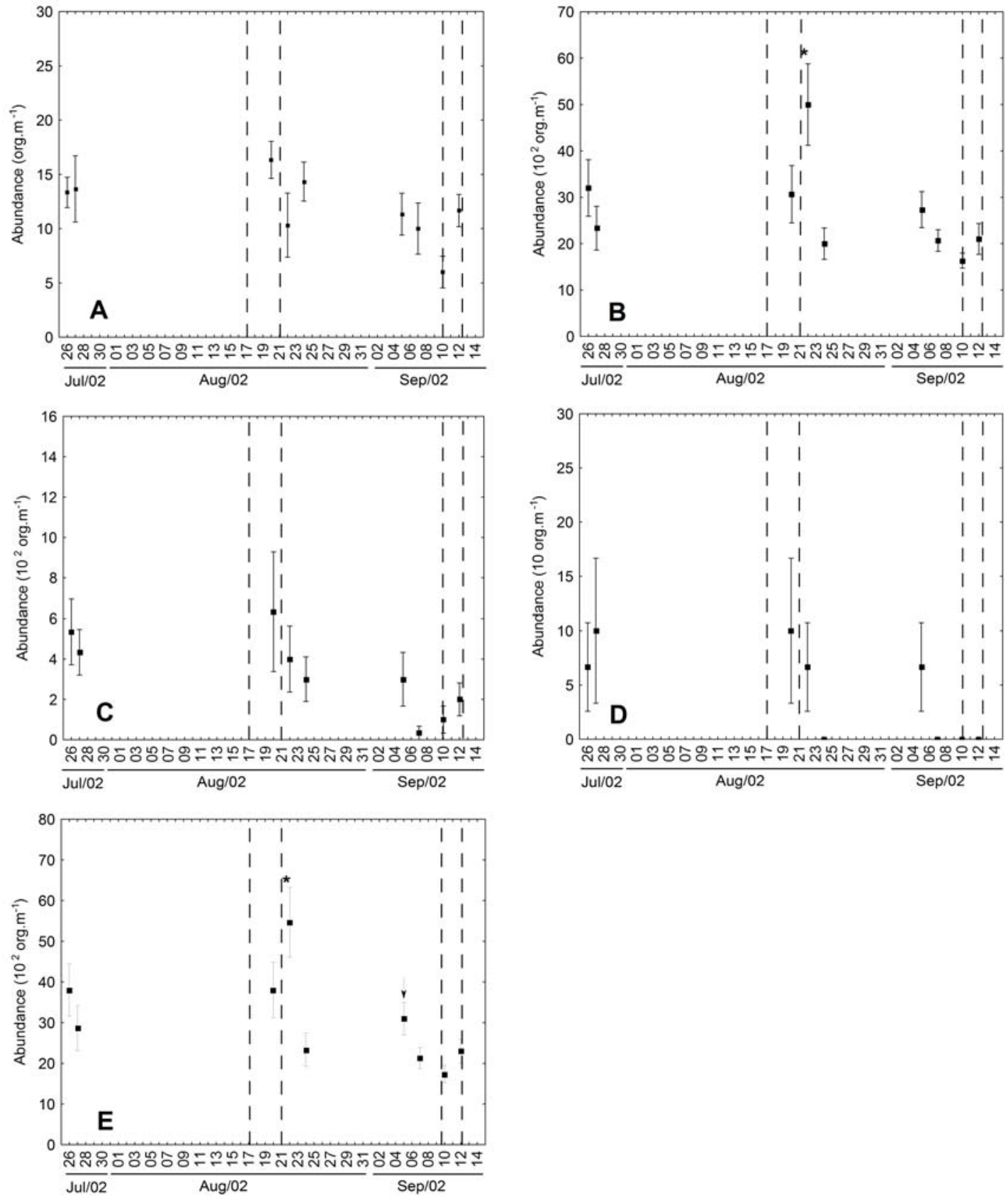

Fig. 7. Mean abundance (+ Standard Error) of O. quadrata (A), E. braziliensis (B), E. brasiliensis (C), D. hanleyanus (D), and total macrofauna (E) recorded between July 26 and September 12 of 2002 at Taquaras beach. * and $\downarrow$ indicate significant differences registered by Tukey's test in sampling carried out during the high energy events which occurred in August and September, respectively. Dotted lines indicate the storm periods. 
No significant variations in the mean abundance of Puelche sp. were seen, as regards the August event, as between the prior sampling and the peak of high wave energy but its abundance was significantly higher after the drop in wave height (August 24). By contrast, during the September event, a significant reduction in the abundance of Puelche sp. was observed with the increase in wave height and the later weakening of the storm (September 10 and 13). A similar pattern was observed for $P$. zimeri, $D$. gemmula and B. brasiliensis (Fig. 8). For the latter two species, there were significant differences between the prior samples corresponding to the September and August events, respectively.

Table 4. Results of the ANOVAs conducted for the species collected during the high energy events of August (26/7 to 24/8) and September (6/9 to 13/9) 2002, on Navegantes beach. DF: degrees of freedom.

\begin{tabular}{|c|c|c|c|c|c|c|}
\hline \multirow{2}{*}{ Species } & \multicolumn{3}{|c|}{ August /2002 } & \multicolumn{3}{|c|}{ September/2002 } \\
\hline & $\mathrm{DF}$ & $\mathrm{F}$ & $\mathrm{p}$ & DF & $\mathrm{F}$ & $\mathrm{p}$ \\
\hline Ocypode quadrata & 4 & 22.73 & $<0.001$ & 3 & 28.74 & $<0.001$ \\
\hline Atlantorchestoidea. brasiliensis & 4 & 0.00 & 1.00 & 3 & 0.67 & 0.58 \\
\hline Excirolana braziliensis & 4 & 1.16 & 0.36 & 3 & 0.03 & 0.99 \\
\hline Excirolana. armata & 4 & 1.55 & 0.22 & 3 & 0.63 & 0.61 \\
\hline Donax hanleyanus & 4 & 0.81 & 0.53 & 3 & 0.61 & 0.61 \\
\hline Scolelepis sp. & 4 & 0.59 & 0.67 & 3 & 1.28 & 0.31 \\
\hline Euzonus furciferus & 4 & 1.10 & 0.38 & 3 & 0.96 & 0.43 \\
\hline Emerita brasiliensis & 4 & 1.24 & 0.32 & 3 & 2.20 & 0.13 \\
\hline Puelche sp. & 4 & 7.24 & 0.001 & 3 & 6.18 & 0.005 \\
\hline Phoxocephalopsis zimeri & 4 & 12.02 & 0.001 & 3 & 9.32 & 0.001 \\
\hline Macrochiridothea giambiageae & 4 & 2.14 & 0.11 & 3 & 0.35 & 0.79 \\
\hline Bathyporeiapus ruffoi & 4 & 1.48 & 0.25 & 3 & 0.96 & 0.43 \\
\hline Bowmaniella brasiliensis & 4 & 4.73 & 0.007 & 3 & 7.08 & 0.003 \\
\hline Lepidopa richmondi & 4 & 1.84 & 0.16 & 3 & 1.04 & 0.40 \\
\hline Donax gemmula & 4 & 110.80 & $<0.001$ & 3 & 44.37 & $<0.001$ \\
\hline Total & 4 & 1.29 & 0.31 & 3 & 3.47 & 0.06 \\
\hline
\end{tabular}



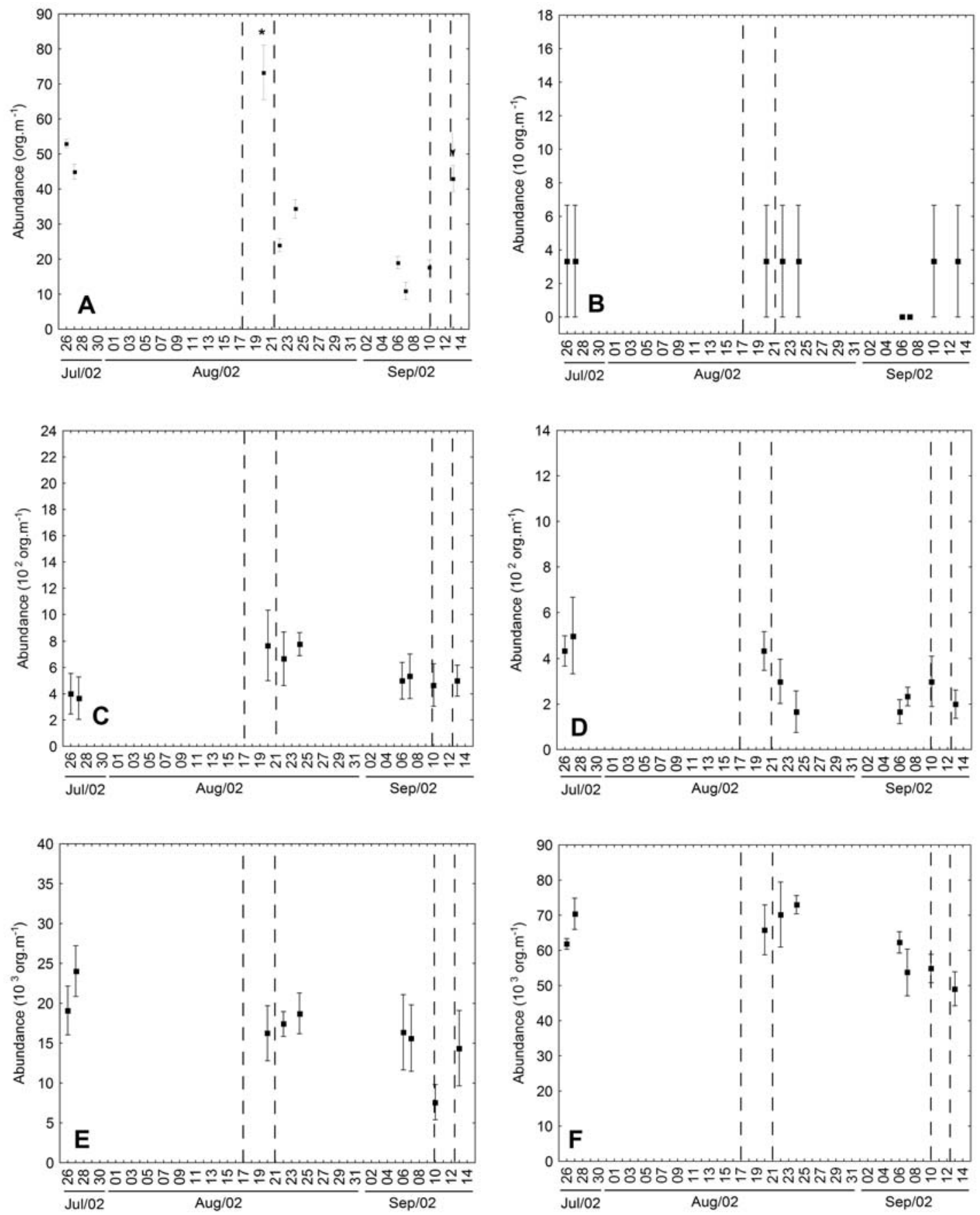

Fig. 8. Mean abundance ( \pm Standard Error) of O. quadrata (A), A. brasiliensis (B), E. braziliensis (C), E. armata (D), E. furciferus (E), Scolelepis sp. (F), D. hanleyanus (G), E. brasiliensis (H), Puelche sp. (I), P. zimeri (J), B. ruffoi $(\mathrm{K})$, L. richmondi $(\mathrm{L})$, B. brasiliensis $(\mathrm{M})$, D. gemmula $(\mathrm{N})$, M. giambiageae $(\mathrm{O})$ and total macrofauna $(\mathrm{P})$ recorded between July 26 and September 13 of 2002 on Navegantes beach. * and $\downarrow$ indicate significant differences registered by Tukey's test in sampling carried out during the high energy events which occurred in August and September, respectively. Dotted lines indicate the storm periods. 

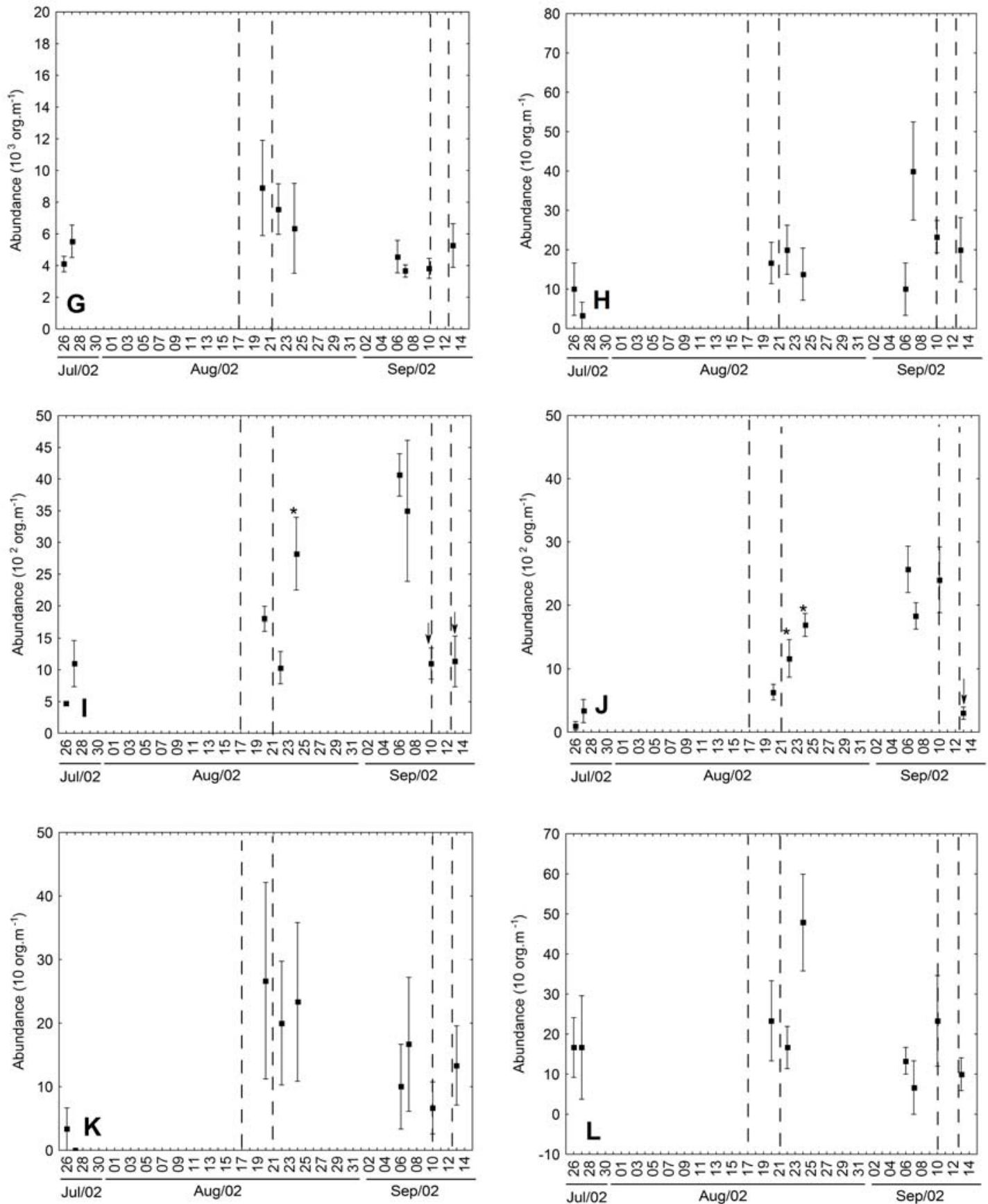

Fig. 8. Cont. 

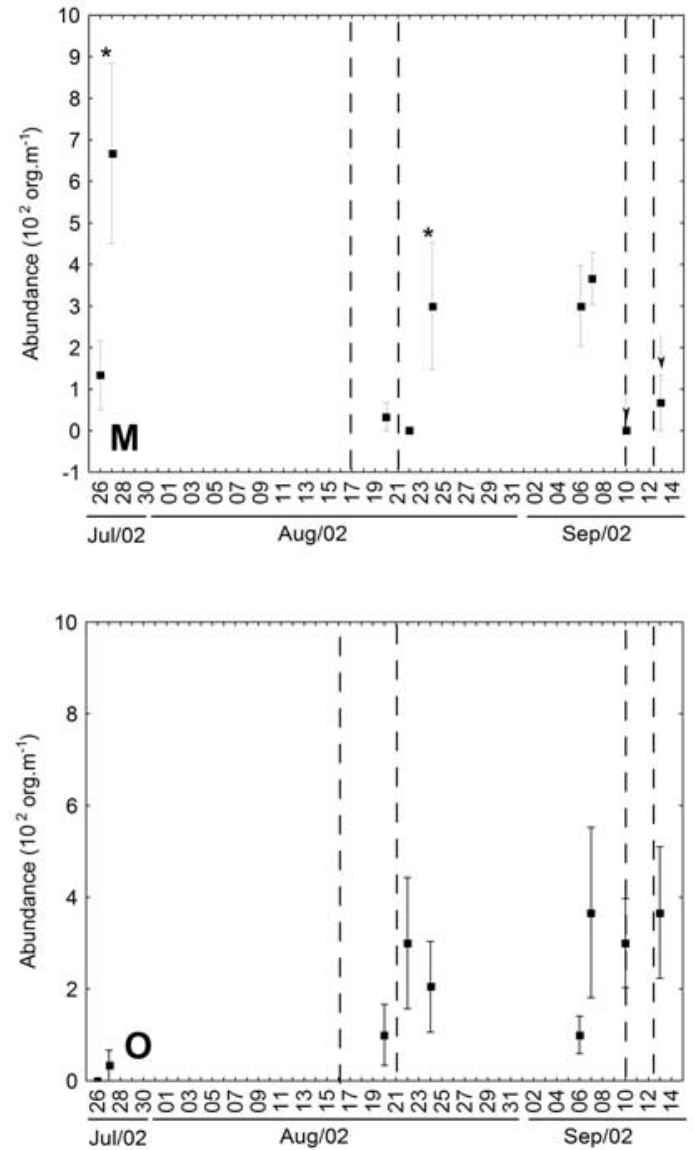

Fig. 8. Cont.

\section{Zonation}

No variations in the zonation pattern of the benthic macrofauna, resulting from high energy events, were observed at Taquaras. In general, two zones were identified throughout the entire period monitored on this beach (Figs 9 and 10). Only on August 24 was a third zone, characterized by the presence of the isopod Tylos niveus (T1), identified on the uppermost level of this beach (Fig. 9C). At other times the upper zone (T2) was characterized by $O$. quadrata and E. braziliensis and by reduced levels of sediment moisture $(<3 \%)$, extending from the region next to the beach vegetation to the upper limit of the swash zone. The second zone (T3) was restricted to the lower levels of the beach, corresponding to the swash zone, and was characterized by $D$. hanleyanus and/or Emerita brasiliensis and by high levels of sediment moisture (Figs 9 and 10).

Although the zonation pattern of this beach underwent no alteration, a greater proximity was observed between the zones during both events. Zone
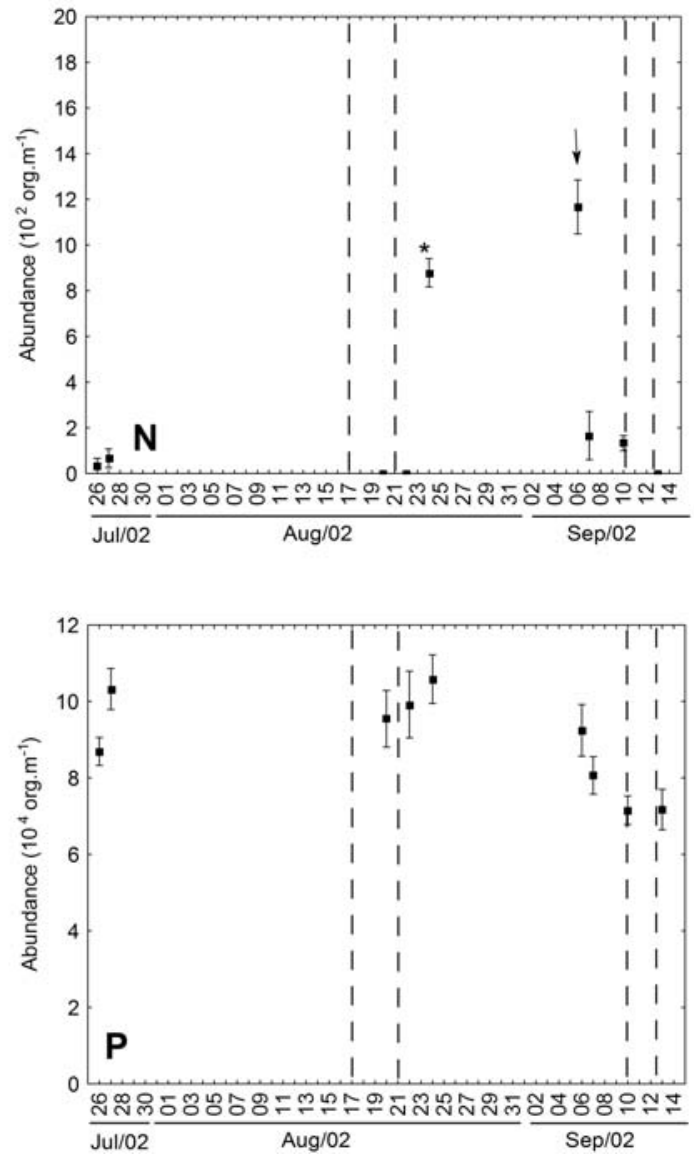

T3 accompanied the variations in the position of the swash zone, and moved up the beach, as a result of the rise in the sea level (Figs 9 and 10).

At Navegantes, three zones were identified during July and August, relating to the first event monitored (Fig. 11). The upper zone (N1) was located near the drift line and was characterized by reduced levels of sediment moisture $(<5 \%)$ and by the presence of A. brasiliensis, E. braziliensis and $O$. quadrata. The second zone (N2) occurred between the drift line and the upper limit of the swash zone, in locations with high moisture (15 to $20 \%)$ and comprised E. furciferus, E. armata and D. hanleyanus. The lower level of this beach, corresponding to the swash zone and the region immediately above, was characterized by Scolelepis sp., E. brasiliensis, Puelche sp., P. zimeri, B. ruffoi, L. richmondi, B. brasiliensis, M. giambiageae, D. gemmula and $A$. patagoniensis, thus constituting the third zone (N3).

The only alteration observed during the August event, was the greater proximity of the $\mathrm{N} 2$ and $\mathrm{N} 3$ 

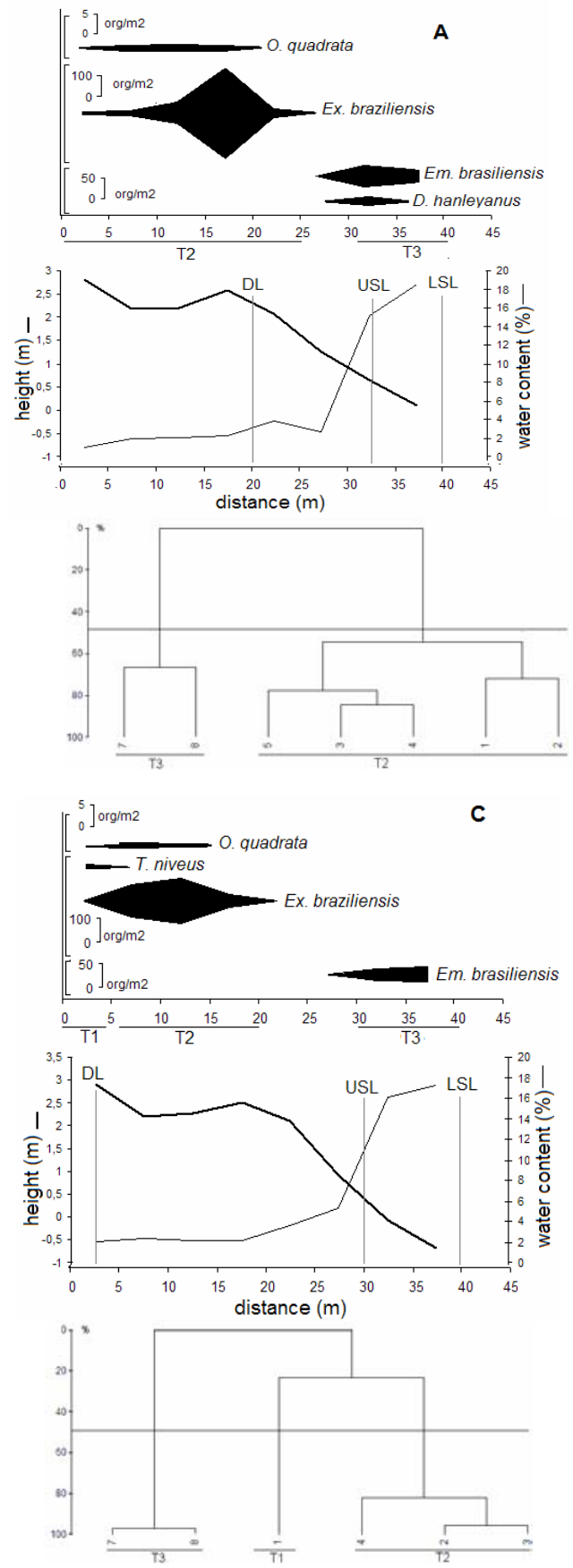

zones during the cold front (August 20). In addition, the N2 zone was characterized not only by the presence of $E$. armata, $E$. furciferus and $D$. hanleyanus but also of Puelche sp. and Scolelepis sp. (Fig. 11B), commonly found in the lower adjacent zone (N3). It should be pointed out that although
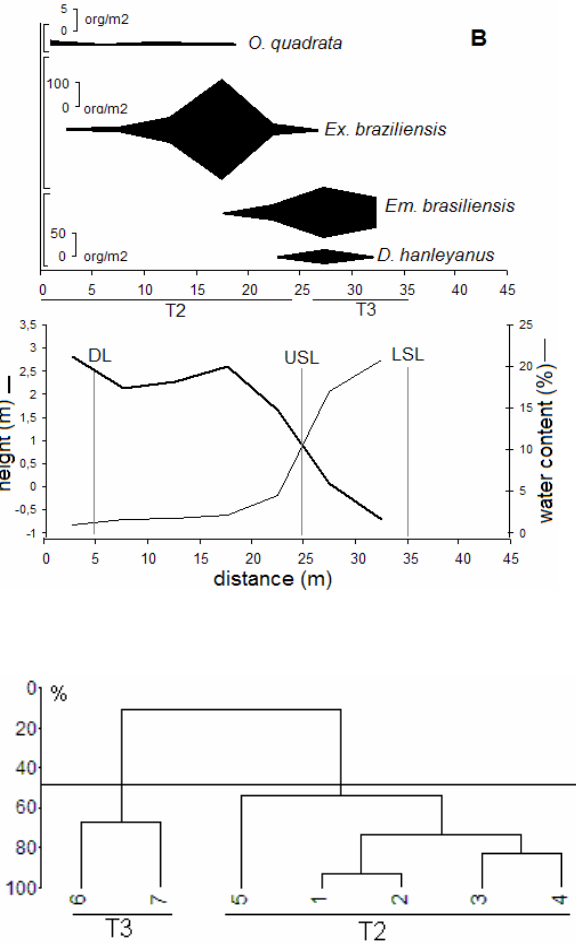

Fig. 9. Macrobenthic zonation, beach morphology, moisture content and cluster analysis of Taquaras Beach during the August, 2002 event. (A): July 26, prior sampling, (B): August 20, during the disturbance; (C): August 24, subsequent sampling. DL: drift line; USL: upper swash limit; LSL: lower swash limit. The numbers in the cluster correspond to sampling stations. cluster analysis identified the formation of a group consisting of stations 1, 2 and 3 during the period, this did not constitute a zone per se, but represented the extremity of the N1 zone, which was the result of an extended distribution of $O$. quadrata toward the dunes (Fig. 11). 

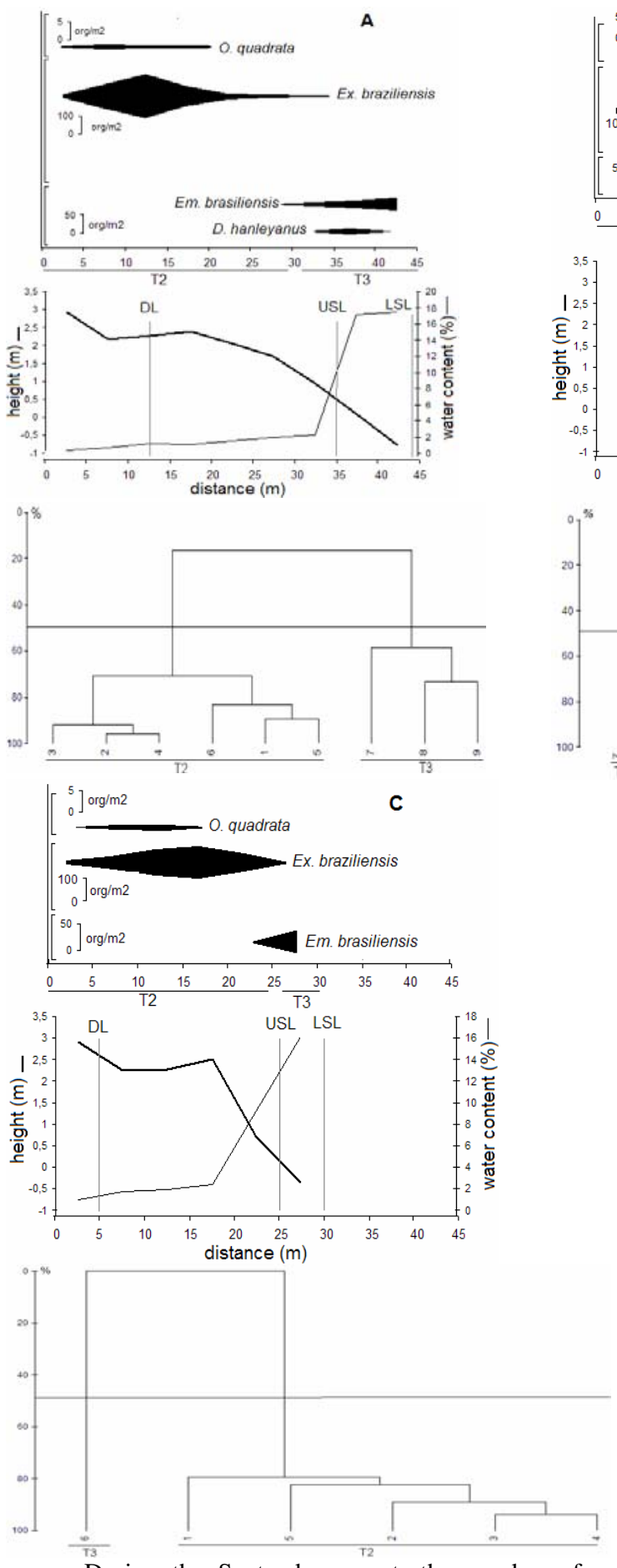

During the September event, the number of zones on Navegantes varied (Fig. 12). Four groups were formed at the two prior samplings (September 6 and 7), as a result of the splitting of the N2 zone into
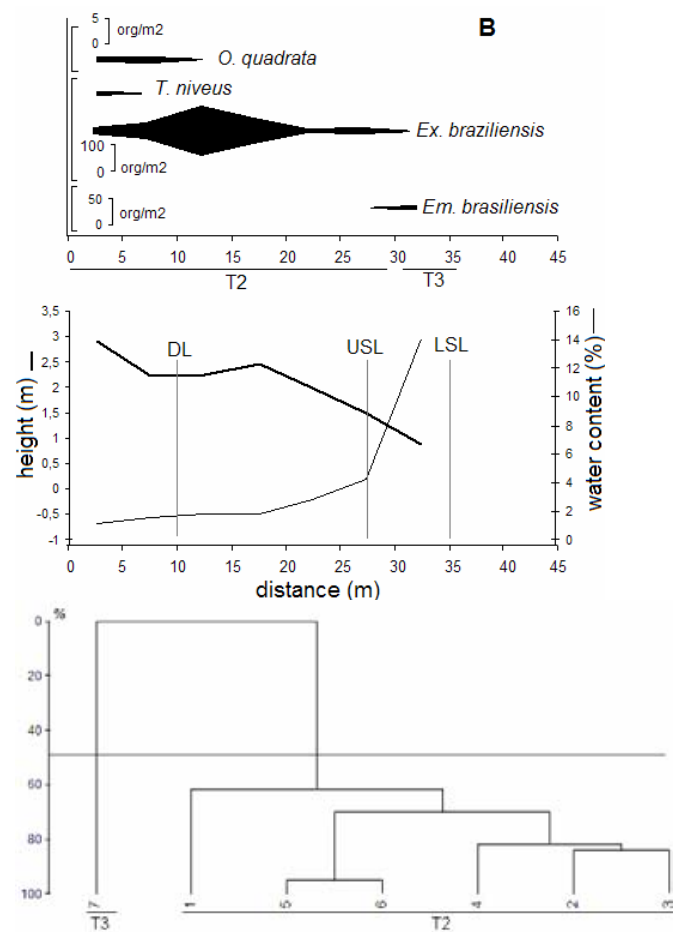

Fig. 10. Macrobenthic zonation, beach morphology, moisture content and cluster analysis of Taquaras Beach during the September, 2002 event. (A): September 5, prior sampling, (B): September 7, prior sampling; (C): September 12, during disturbance. DL: drift line; USL: upper swash limit; LSL: lower swash limit. The numbers in the cluster correspond to sampling stations. two subgroups: an upper one formed by E. armata (N2a) and a lower one comprising E. furciferus (N2b) (Fig. 12A). This splitting was probably caused by the alteration in the distribution of $E$. armata, which 
occurred on the upper levels of the beach as compared with that of the preceding event (Fig. 11).

With the increase in wave height on September 10 , only three zones were identified on Navegantes, as species characteristic of the swash zone were displaced to upper levels of the beach, thus causing the fusion of zones N2b and N3 (Fig. 12B). Soon after the passage of the cold front (September 13), the number of zones on this beach remained the same (3), but with distinct species composition (Fig. 12C), similar to that observed for samplings performed between July and August (Fig. 11)

During all the September samplings, the N1 zone showed a species composition similar to that reported for August at Navegantes, but localized on upper levels of the beach and including sampling stations 1 and 2, not previously characterized as a zone (Figs 11 and 12). The displacement of this zone and of E. armata to upper levels of the beach in September, coincided with the changes in the sediment moisture gradient observed after the passage of the first cold front (Fig. 6).

\section{Discussion}

The cold fronts monitored in this study caused marked alterations in the hydrodynamic conditions at Taquaras and Navegantes and led to different effects on their morphological characteristics, as the magnitude and velocity of the erosive and depositional processes were very distinct between the morphodynamic extremes.

As expected on the basis of its reflective characteristics, Taquaras showed a greater susceptibility to higher waves and was characterized by marked morphological changes. During both cold fronts, intense erosive processes were observed mainly on the middle and lower levels of its sub-aerial profile. In addition, it was characterized by a rapid capacity for the restoration of the beach profile.

In contrast, at the dissipative extreme, the erosive processes resulting from the cold fronts operated in a slow and progressive manner on the subaerial profile. Morphological changes of low intensity were observed along the Navegantes beach profile during the first event (August) and only some days after the storm peak. The morphological changes resulting from this erosive process persisted up to the end of this study, indicating that this beach was characterized by a reduced capacity for recovery of its sub-aerial profile.

Disturbances in the sediment associated with storms and/or wave action can have a great influence on the species composition and abundance of the benthic macrofauna (AUBREY, 1983; POSEY et al., 1996). Massive mortality of benthic organisms as a result of storm events have been recorded for exposed sandy beaches due to erosive processes and alterations in the position of the swash zone (FITCH, 1950; MCLACHLAN et al., 1996). Although marked changes in beach morphology, and to a lesser degree, in the localization of the swash zone were observed at Taquaras, species richness and abundance of the macrofauna did not show any significant decreases during the high energy events studied. This was observed both for species characteristic of the upper levels of the beach (O. quadrata and E. braziliensis) as for those of the lower ones (E. brasiliensis and $D$. hanleyanus), where most of the erosive and depositional processes was recorded.

The only alteration observed for the macrobenthos at Taquaras during the period monitored was a significant increase in the abundance of $E$. braziliensis on August 22, which coincided with the weakening of the first event. This change appeared to have been determined by some factor related specifically to the high energy system, since the original abundance levels were reestablished soon after the end of the event.

According to Soares et al. (1996) and Colombini et al. (2000), material stranded on the beach surface constitutes a highly dynamic source of food which influences the temporal and spatial strategies of the sandy beach macrofauna and may have caused the increase in the abundance of $E$. braziliensis. In fact, the weakening of wave energy which started on August 22, induced not only the accretion to the profile at Taquaras but also the deposition on the beach face of stranded material removed from adjacent rocky shores during the storm. A drift line composed mainly of fragments of algae was detected on this occasion exactly at the station where the greatest density of the species was found, probably due to an aggregation of $E$. braziliensis around its food source. The same phenomenon was recorded at Taquaras in September, 2000 , coinciding with a high-energy event that made stranded material available on the beach face (ALVES, 2004).

No increase in abundance was found for $E$. braziliensis during the cold front of September, 2002 at Taquaras. This may have resulted from the fact that sampling was interrupted before the complete weakening of the high-energy system. Despite the fact that a large amount of particulate material removed from adjacent rocky coasts was available in the surf zone during the last day of sampling (September 12), the erosive conditions prevailing on the occasion limited the deposition of this material on the beach. The occurrence of this aggregation of E. braziliensis exclusively on Taquaras may be explained by differences between the morphodynamic extremes in relation to: a) the type and origin of food available, and $b$ ) its frequency of occurrence. 

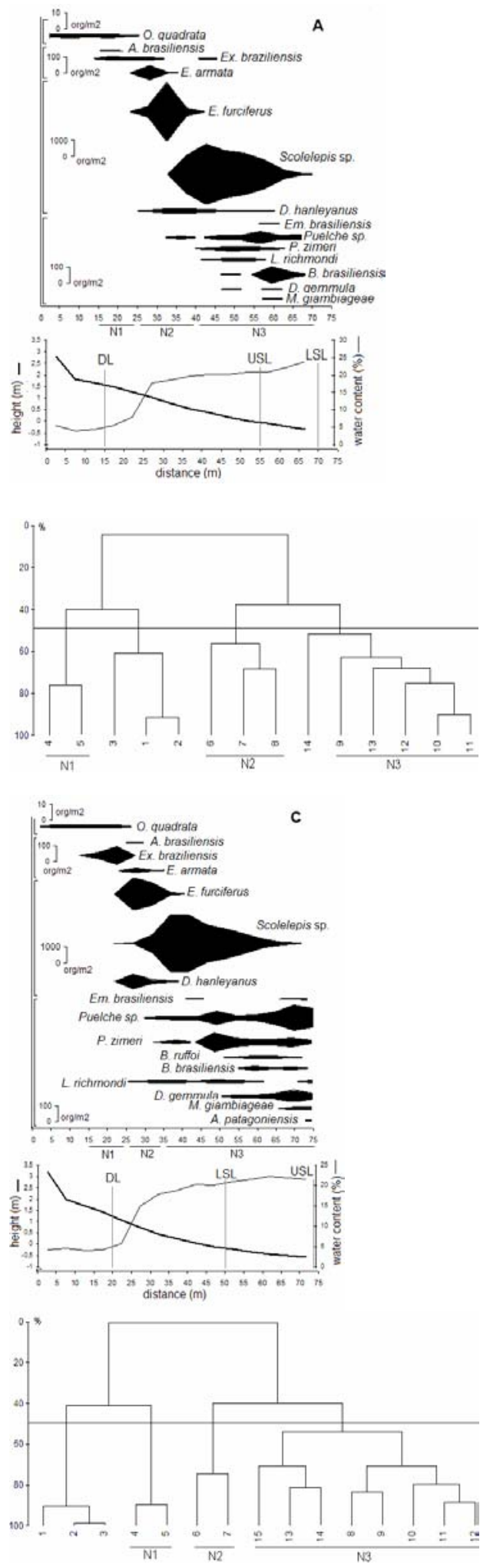
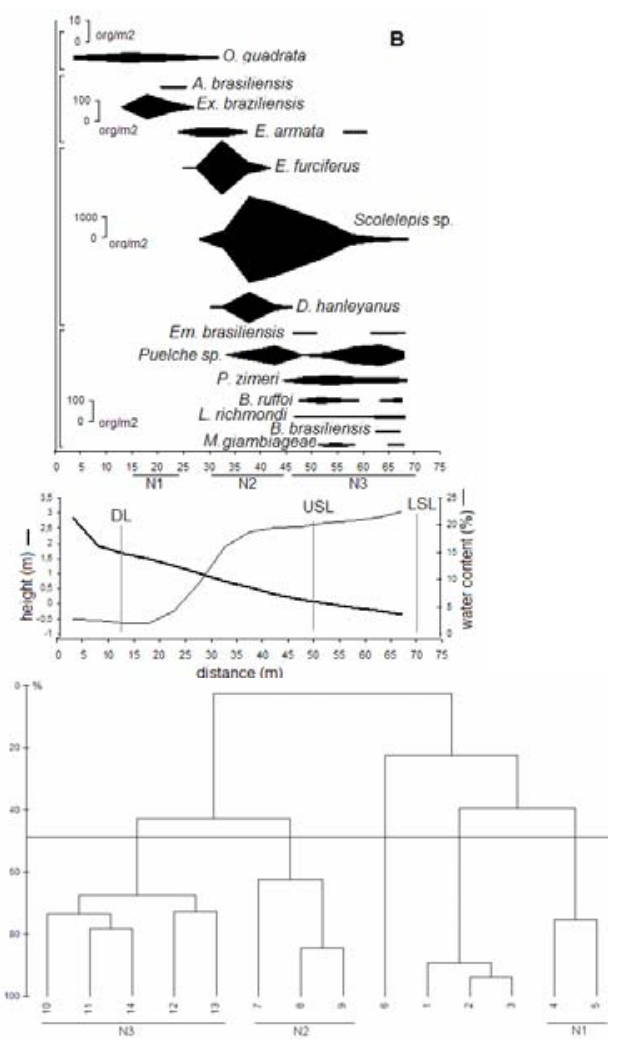

Fig. 11. Macrobenthic zonation, beach morphology, moisture content and cluster analysis of Navegantes Beach during the August, 2002 event. (A): July 27, prior sampling, (B): August 20, during the disturbance; (C): August 24, subsequent sampling. DL: drift line; USL: upper swash limit; LSL: lower swash limit. The numbers in the cluster correspond to sampling stations. 

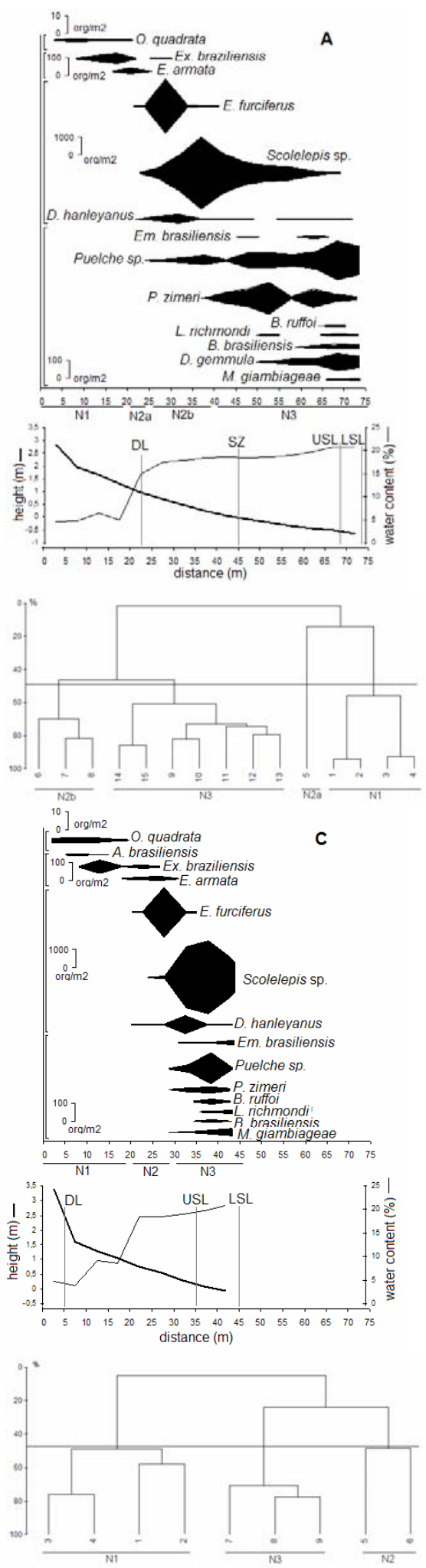
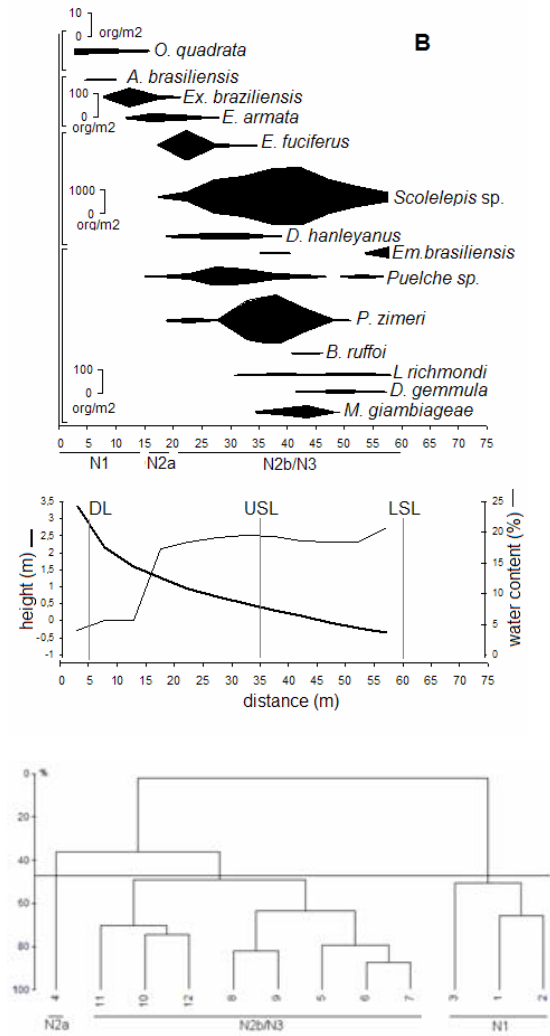

Fig. 12. Macrobenthic zonation, beach morphology, moisture content and cluster analysis of Navegantes Beach during the September, 2002 event. (A): September 6, prior sampling, (B): September 10, during disturbance; (C): September 13, soon after disturbance. DL: drift line; USL: upper swash limit; LSL: lower swash limit. The numbers in the cluster correspond to sampling stations. 
E. braziliensis is characterized by necrophagous/detritivorous habits (SOUZA; GIANUCA, 1995) and depends, to a large extent, on particulate material and/or carcasses of animals stranded on the beach. Based on the erratic nature of this food source (MCLACHLAN; BROWN, 2006), these organisms present opportunistic feeding behavior, characterized by a) capacity to ingest and store large quantities of food, and b) slow digestion and utilization of ingested food over long periods of time. This high energy system apparently had, therefore, a positive effect on the benthic macrofauna of this beach, at least at the intensity and duration considered in this study. The passage of cold fronts not only did not reduce the abundance of the fauna, but rather made food available for this system, generally destitute of resident primary producers and, thus, dependent on the importation of material from nearby environments (MCLACHLAN; BROWN, 2006).

Nor was there any evidence of negative effects on the species composition and abundance of the benthic macrofauna induced by cold fronts, at Navegantes. Significant changes in the abundance of some species in the samples appear to have been due, at least in part, to alterations in sea level. The increase in the abundance of Puelche sp., P. zimeri and D. gemmula on August 24 and September 6, coincided with the lowest sea levels recorded at Navegantes throughout the study. In the same manner, the significant reduction in abundance of Puelche sp., $P$. zimeri and $B$. brasiliensis during the second event coincided with the great rise in sea level observed on that occasion. All these species are predominantly infralittoral. Therefore, the decrease in their abundance during the September event does not appear to have been caused by the direct effect of the cold front on the fauna but by a reduction in the area available for sampling, which included only the upper boundary of the distribution of these species, as suggested by the zonation patterns determined for the period.

In essence, during the whole period monitored, the greatest changes in the abundance of the fauna of Navegantes occurred in species living in the lowest levels of the beach. With the exception of O. quadrata, whose abundance was significantly higher during the two cold fronts, the other species distributed exclusively on the sub-aerial beach profile showed no significant variations in this parameter.

The results obtained showed that on the two beaches studied, the mean abundance of many species was more variable between the different events and/or control samples in the absence of cold fronts, than during increased wave height and/or beach erosion observed within the same event. This suggests that cold front disturbances, with the intensity and duration observed in this study, did not influence the temporal variability of the composition and abundance of macrobenthos more than recruitment processes and natural environmental variability observed throughout the year on the beaches studied. In fact, the population fluctuations at Taquaras and Navegantes were considerably more intense as among the monthly samplings conducted by Alves (2004) than during the cold fronts. These results suggest that the high energy events monitored in this study were not strong enough to disturb the macrobenthic communities on either beaches.

This does not mean, however, that energetic expenditure does not exist for maintenance and survival under such stressful conditions. Laboratory tests conducted with $D$. hanleyanus collected during the cold front of August, 2002 showed greater physiological stress in organisms from Taquaras than from Navegantes (MARTINS et al., 2006). According to these authors, this resulted from the higher energetic expenditure necessary for excavation under conditions of intense sediment remobilization, in order to avoid being removed from the beach with the sediment. That is, the physiological processes of $D$. hanleyanus may be affected by high energy events, but with different magnitudes - depending on the intensity of the environmental changes that cold fronts can produce on each beach type. Therefore, the duration, frequency and intensity of this high energy system should be considered when analyzing their effects on the fauna.

When investigating the effect of a meteorological front passing over a dissipative beach in Paraná, Cochôa et al. (2006) observed that the zonation patterns of macrobenthos were only slightly affected by changes in the physical environment caused by the storm. Only a discreet reduction and approximation of the distribution area of the organisms were observed after the front as a result of: a) the environmental homogeneity produced by the smoothing of the beach profile, which permitted the spreading of the species; and b) the passive transport of organisms by the violent removal of sediment due to the waves.

In the present study, short-term changes in the macrobenthic distribution, induced by cold fronts, were observed on the two beaches and were more related to variations in the sea level and positioning of the swash zone than to sediment remobilization. On the other hand, changes in beach morphology and in the resultant moisture gradient accounted for effects of longer duration in the distribution of some species at the dissipative extreme.

In spite of the intense morphological alterations observed on Taquaras during cold fronts, the zonation pattern of its macrofauna remained unaltered. Only a greater proximity between the zones 
occurred during both events. The zone of the lower level of the beach (T3), formed exclusively by intertidal migrants, accompanied the changes in the position of the swash zone and shifted to upper levels of the profile, as a result of the rising sea level observed during the events.

Besides the approximation between the zones, the rise in sea level at Navegantes and the shifting of the swash zone during the cold fronts resulted in an overlapping in the distribution of the species and alterations in the species composition of the zones. These changes were more evident in September 2002, coinciding with the greatest rise in sea level and, consequently, with a larger transport of intertidal migrants by the swash. As erosive processes were not verified on this occasion at Navegantes, short-term changes in the species distribution of dissipative sandy beaches appear to be more related to the positioning of the swash zone than to sediment remobilization. In September, the distribution of A. brasiliensis, $O$. quadrata and Excirolana braziliensis shifted to higher levels of the beach than in August. This can be explained by the fact that the erosion caused by the first cold front persisted up to the end of the second event, causing persistent changes in the moisture gradient. The fact that the reduction of the distribution area of these species coincided with a reduction in the extension of the area with low sediment moisture levels, supports this idea. This suggests that on dissipative beaches morphological alterations caused by cold fronts can lead to long-term changes in moisture gradients and, consequently, in the distribution of the benthic macrofauna due to the reduced capacity for the recovery of dissipative beach profiles.

The results obtained suggest that short-term and unpredictable environmental disturbances of the intensity and duration considered in this study, do not cause significant changes in the composition and abundance of the benthic macrofauna of exposed sandy beaches in Santa Catarina, regardless of their morphodynamic state. Therefore, medium-scale processes such as recruitment and environmental variability (over the course of the year) appear to exercise a greater determining effect on the structure of their benthic macrofauna (ALVES, 2004).

On the other hand, changes in the spatial structure of the benthic macrofauna can occur during events of this nature, due to changes in sea level, positioning of the swash zone and moisture gradient. These variations tend to be more intense and longerlasting at the dissipative extreme as a result of greater variations in the position of the swash zone, a less discrete moisture gradient and a lower capacity for recovery of the profile of this type of beach.

Cold fronts of greater magnitude and erosive power are sporadic in the region and occur generally in association with meteorological tides (KLEIN et al., 2002b). Future studies should, therefore, be focused on investigating events of different intensity and duration to determine the sensitivity of organisms to high energy events of distinct magnitudes.

\section{ACKNOWLEDGMENTS}

This manuscript is part of the Doctoral Thesis written by the first author under the supervision of Dr. Sérgio de Almeida Rodrigues (Instituto de Biociências da Universidade de São Paulo - IB/USP) who, we regret to record, passed away just before the conclusion of the project. The authors are also grateful to Dr. Gisela Y. Shimizu (IB/USP) for her kind assistance during the last part of the course.

\section{REFERENCES}

ALVES, E. S. O efeito da morfodinâmica praial e suas variações temporais de curto e médio prazo sobre a macrofauna bentônica de três praias arenosas expostas de Santa Catarina, Brasil. 2004. 247 p. Tese (doutorado) - Instituto de Biociências, Universidade de São Paulo, São Paulo., 2004.

ALVES, E. S.; RODRIGUES, S. A.; PEZZUTO, P. R.; SHIMIZU, G. Y. Caracterização ambiental da porção subaérea de praias arenosas expostas com diferentes características morfodinâmicas no litoral centro-norte de Santa Catarina, Brasil. Notas Téc. FACIMAR, v. 8, p. 1-24, 2004.

ALVES, J. H. G. M.; MELO, E. Measurement and modeling of wind waves at the northern coast of Santa Catarina, Brazil. Revta. Bras. Oceanogr., v. 49, n. 1-2, p. 13-28, 2001.

AUBREY, D. G. Beach changes on coasts with different wave climates. In: McLachlan, A.; Erasmus, T. (eds.). Sandy beaches as ecosystems. The Hague: W. Junk, 1983, p. 63-85.

BIRKEMEIER, W. A. Fast accurate two-person beach survey Coast. Eng. Tech. Aid 81-11, U. S. Army Engineer Waterways Experiment Station, Coastal Engineering Research Center, Mississipi, 1981. 22 p. BRAZEIRO, A.; DEFEO, O. Macroinfauna zonation in microtidal sandy beaches: is it possible to identify patterns in such variable environments? Estuar. coast. Shelf Sci., v. 42, p. 523-536, 1996.

BROWN, A. C. Behavior plasticity as a key factor in the survival and evolution of the macrofauna on exposed sandy beaches. Rev. Chil. Hist. Nat., v. 69, n. 4, p. 469474, 1996.

CALLIARI, L. J.; TOZZI, H. A. M.; KLEIN, A. H. F. Beach morphology and coastline erosion associated with storm surges in southern Brazil - Rio Grande to Chuí, RS. An. Acad. Bras. Ciênc. , v. 70, n. 2, p. 231-247, 1998.

COCHÔA, A. R.; LORENZI, L.; BORZONE, C. A. A influência da passagem de uma frente meteorológica na distribuição da macrofauna bentônica mesolitoral de uma praia arenosa exposta. Tropic. Oceanogr., v. 34, n. 2, p. 59-71, 2006. 
COLOMBINI, L.; ALOIA, A.; FALLACI, M.; PELOZZI, G.; CHELAZZI, L. Temporal and spatial use of stranded wrack by the macrofauna of a tropical sandy beach. Mar. Biol.,v. 136, p. 531-541, 2000.

CROCKER, R. A. Distribution and abundance of some intertidal sand beach amphipods accompanying the passage of two hurricanes. Chesapeake Sci., v. 9, n. 3: p. 157-162, 1968.

DEFEO, O. Experimental management of an exploited sandy beach bivalve population. Rev. Chil. Hist. Nat., v. 69, p. 605-614, 1996.

FITCH, J. E. The pismo clam. Calif. Fish Game, v. 36, p. 285-312, 1950.

GALLUCCI, F.; NETTO, S. A. Effects of the passage of cold fronts over a coastal site: an ecosystem approach. Mar. Ecol. Prog. Ser., v. 281, p. 79-92, 2004.

KLEIN, A. H. F.; MENEZES, J. T. Beach morphodynamics and profile sequence for a headland bay coast. J. coast. Res., v. 17, n. 4, p. 812-835, 2001

KLEIN, A. H. F.; BENEDET FILHO, L.; SCHUMACHER, D. H. Short-term beach rotation processes in distinct headland bay beach systems. J. coast. Res., v. 18, n. 3, p. 442-458, 2002a.

KLEIN, A. H. F.; DIEHL, F. L.;RIBEIRO Jr., O.; BENEDET FILHO, L.O litoral de Santa Catarina e a ocupação desordenada das suas praias. Gerenciam. cost. integr. v. 2, n. 1, p. 6-7, 2002b.

LEGENDRE, P.; LEGENDRE, L. Numerical ecology. 2th edition. Amsterdam: Elsevier, 1998. 851 p.

MARTINS, L. K. P.; BELlOTTO, V. R.; ALVES, E. S.; BRITO, P. C. Effect of a storm event on lysosomes of haemocytes in Donax hanleyanus (Mollusca: Bivalvia) on exposed sandy beaches of Santa Catarina State, Brazil. J. coast. Res., SI 39, p. 1814-1818, 2006.

MCLACHLAN, A.; BROWN, A. C. Ecology of sandy shores. Oxford: Elsevier. 2006. 328 p.

McLACHLAN, A.; DUGAN, J. E.; DEFEO, O.; ANSELL, A. D.; HUBBARD, D. M.; JARAMILLO, E.; PENCHASZADEH, P. E. Beach clam fisheries. Oceanogr. mar. Biol., a. Rev., v. 34, p. 163-232, 1996.

NOBRE, C. A.; CAVALCANTI, M. A. G.; NOBRE, P.; KAYANO, M. T.; RAO, V. B.; BONATTI, J. P.; SATYAMURTI, P.; UVO, C. B.; COHEN, J. C. Aspectos da climatologia dinâmica do Brasil. Climanálise, Número especial, 1986.
POSEY, M.; LINDBERG, W.; ALPHIN, T.; VOSE, F. Influence of storm disturbance on an offshore benthic community. Bull. mar. Sci., v. 59, n. 3, p. 523-529, 1996.

SALOMAN, C. H.; NAUGHTON, S. P. Effect of Hurricane Eloise on the benthic fauna of Panama city beach, Florida, USA. Mar. Biol., v. 42, p. 357-363, 1977.

SCHETTINI, C. A. F. Caracterização física do estuário do rio Itajaí-açu, SC. Revta Bras. Rec. hídric., v. 7, n. 1, p. 123-142, 2002.

SCHETTINI, C. A. F.; CARVALHO, J. L.; TRUCCOLO, E. C. Aspectos hidrodinâmicos da enseada da Armação de Itapocoroy, SC. Notas Téc. FACIMAR, v. 3, p. 99-109, 1999.

SHORT, A. D. Handbook of beach and shoreface morphodynamics. Chinchester: John Wiley \& Sons, 1999. $491 \mathrm{p}$.

SOARES, A. G.; McLACHLAN, A.; SCHALACHER, T. A. Disturbance effects of stranded kelp on populations of the sandy beach bivalve Donax serra (Röding). J. expl Mar. Biol. Ecol., v. 205, p. 165-186, 1996.

SOLA, M. C. R.; PAIVA, P. C. Variação da macrofauna bentônica sublitoral da praia da Urca (RJ) após a ocorrência de ressacas. Rev. Bras. Oceanogr., v. 49, n. 1-2, p. 137-142, 2001.

SOUZA, J. R. B; GIANUCA, N. M. Zonation and seasonal variation of the intertidal macrofauna on a sandy beach of Paraná State, Brazil. Scientia mar, v. 59, n. 2, p. 103111. 1995.

WRIGHT, L. D.; SHORT, A. D. Morphodynamic variability of surf zones and beaches: synthesis. Mar. Geol., v. 56, p. 93-118, 1984.

ZAR, J. H. Biostatistical analysis. $3^{\text {rd }}$. ed. Upper Saddle River, N J.: Prentice Hall, 1996. 661 p.

(Manuscript received 03 April 2008; revised 18 June 2008; accepted 15 August 2008) 